\title{
Geology of the continental margin of Enderby and Mac. Robertson Lands, East Antarctica: Insights from a regional data set
}

\author{
H.M.J. Stagg ${ }^{1, *}{ }^{*}$ J.B. Colwel ${ }^{1}$, N.G. Direen ${ }^{2}$, P.E. O’Brien ${ }^{1}$, G. Bernardel ${ }^{1}$, I. Borissova ${ }^{1}$, \\ B.J. Brown ${ }^{3} \&$ T. Ishirara ${ }^{4}$ \\ ${ }^{1}$ Geoscience Australia, Camberra, ACT, Australia \\ ${ }^{2}$ Continental Evolution Research Group, University of Adelaide, SA, Australia, \\ ${ }^{3}$ School of Geosciences, The University of Sydney, NSW, Australia \\ ${ }^{4}$ Geological Survey of Japan, Tsukuba, Japan; *Corresponding author (Phone: +61-2-6249-9343; Fax: \\ +61-2-6249-9920; E-mail: Howard.stagg@ga.gov.au)
}

Received 11 November 2003; accepted 30 October 2004

\begin{abstract}
In 2001 and 2002, Australia acquired an integrated geophysical data set over the deep-water continental margin of East Antarctica from west of Enderby Land to offshore from Prydz Bay. The data include approximately $7700 \mathrm{~km}$ of high-quality, deep-seismic data with coincident gravity, magnetic and bathymetry data, and 37 non-reversed refraction stations using expendable sonobuoys. Integration of these data with similar quality data recorded by Japan in 1999 allows a new regional interpretation of this sector of the Antarctic margin.

This part of the Antarctic continental margin formed during the breakup of the eastern margin of India and East Antarctica, which culminated with the onset of seafloor spreading in the Valanginian. The geology of the Antarctic margin and the adjacent oceanic crust can be divided into distinct east and west sectors by an interpreted crustal boundary at approximately $58^{\circ}$ E. Across this boundary, the continent-ocean boundary (COB), defined as the inboard edge of unequivocal oceanic crust, steps outboard from west to east by about $100 \mathrm{~km}$.

Structure in the sector west of $58^{\circ} \mathrm{E}$ is largely controlled by the mixed rift-transform setting. The edge of the onshore ArchaeanProterozoic Napier Complex is downfaulted oceanwards near the shelf edge by at least $6 \mathrm{~km}$ and these rocks are interpreted to underlie a rift basin beneath the continental slope. The thickness of rift and pre-rift rocks cannot be accurately determined with the available data, but they appear to be relatively thin. The margin is overlain by a blanket of post-rift sedimentary rocks that are up to $6 \mathrm{~km}$ thick beneath the lower continental slope.

The $\mathrm{COB}$ in this sector is interpreted from the seismic reflection data and potential field modelling to coincide with the base of a basement depression at 8.0-8.5 s two-way time, approximately $170 \mathrm{~km}$ oceanwards of the shelf-edge bounding fault system. Oceanic crust in this sector is highly variable in character, from rugged with a relief of more than $1 \mathrm{~km}$ over distances of $10-20 \mathrm{~km}$, to rugose with low-amplitude relief set on a long-wavelength undulating basement. The crustal velocity profile appears unusual, with velocities of $7.6-7.95 \mathrm{~km} \mathrm{~s}^{-1}$ being recorded at several stations at a depth that gives a thickness of crust of only $4 \mathrm{~km}$. If these velocities are from mantle, then the thin crust may be due to the presence of fracture zones. Alternatively, the velocities may be coming from a lower crust that has been heavily altered by the intrusion of mantle rocks.

The sector east of $58^{\circ} \mathrm{E}$ has formed in a normal rifted margin setting, with complexities in the east from the underlying structure of the $\mathrm{N}-\mathrm{S}$ trending Palaeozoic Lambert Graben. The Napier Complex is downfaulted to depths of $8-10 \mathrm{~km}$ beneath the upper continental slope, and the margin rift basin is more than $300 \mathrm{~km}$ wide. As in the western sector, the riftstage rocks are probably relatively thin. This part of the margin is blanketed by post-rift sediments that are up to about $8 \mathrm{~km}$ thick.

The interpreted $\mathrm{COB}$ in the eastern sector is the most prominent boundary in deep water, and typically coincides with a prominent oceanwards step-up in the basement level of up to $1 \mathrm{~km}$. As in the west, the interpretation of this boundary is supported by potential field modelling. The oceanic crust adjacent to the COB in this sector has a highly distinctive character, commonly with (1) a smooth upper surface underlain by short, seaward-dipping flows; (2) a transparent upper crustal layer; (3) a lower crust dominated by dipping high-amplitude reflections that probably reflect intruded or altered shears; (4) a strong reflection Moho, confirmed by seismic refraction modelling; and (5) prominent landward-dipping upper mantle reflections on several adjacent lines. A similar style of oceanic crust is also found in contemporaneous ocean basins that developed between Greater India and Australia-Antarctica west of Bruce Rise on the Antarctic margin, and along the $\mathrm{Cu}$ vier margin of northwest Australia.
\end{abstract}




\section{Introduction}

The continental margin off Enderby and Mac. Robertson Lands, East Antarctica, and the adjacent deep ocean basins occupy a key position for the understanding of the Cretaceous breakup of central Gondwana (Greater India and Antarctica). Since the early 1980s, a number of geophysical surveys have been carried out in the region; however, published interpretations of these datasets are scarce and the area is still among the more poorly documented parts of the Antarctic continental margin.

In the austral summers of $2000 / 01$ and 2001/ 02, Australia contracted the acquisition of a major new high-quality multichannel seismic (MCS) dataset of more than 20,000 line-km along the margin of East Antarctica from $38^{\circ} \mathrm{E}$ to $150^{\circ} \mathrm{E}$. During these surveys (Geoscience Australia Surveys GA-228 and GA-229), $7693 \mathrm{~km}$ of 36-fold stacked and migrated deepseismic data (601 airgun array source; $3600 \mathrm{~m}$ streamer; 288 channels; $16 \mathrm{~s}$ record length), together with coincident gravity and magnetics data and 37 refraction/wide-angle sonobuoys were recorded between offshore western Enderby Land and the southern Kerguelen Plateau (38$80^{\circ} \mathrm{E}$; Figures 1 and 2). A further $3425 \mathrm{~km}$ of high-speed seismic data of limited penetration were also recorded during Geoscience Australia Survey GA-227, with transects being concentrated on the upper continental slope. However, less than $300 \mathrm{~km}$ of data from this survey were recorded off Enderby Land, and the interpretation of those lines is not included here. The deepseismic lines extend from the mid-continental slope northward to oceanic crust and were regularly spaced at approximately $90 \mathrm{~km}$ along the margin. Where they are tied to previously recorded multichannel seismic data (TH99 survey; Joshima et al., 2001; Geoscience Australia Survey 33; Stagg, 1985), they allow transects of the margin to be interpreted from the continental shelf out to oceanic crust emplaced during the separation of India and Antarctica in the Cretaceous.

The main part of the paper concentrates on an interpretation of these new seismic data. While this interpretation is primarily based on the seismic reflection data, we also present results of non-reversed sonobuoy stations and then

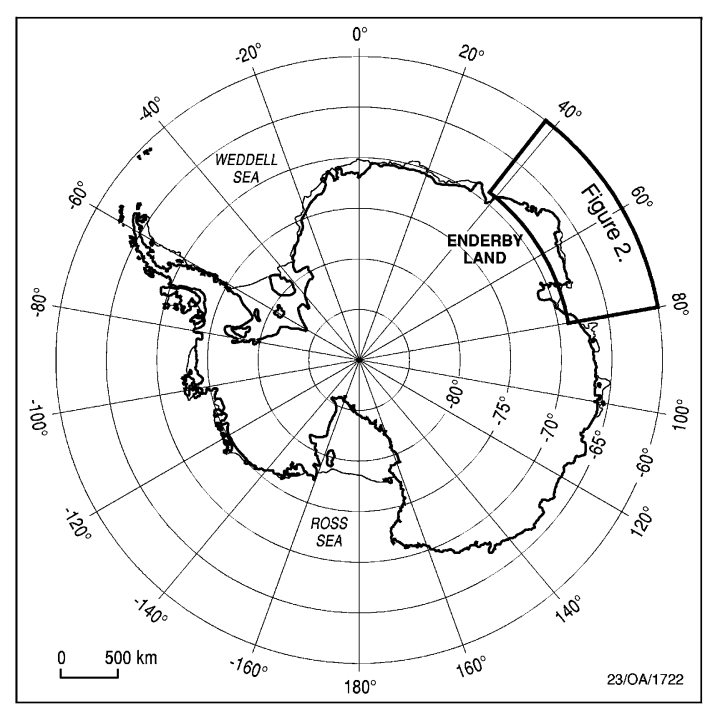

Figure 1. Antarctica, showing the study area for this paper.

integrate velocity, reflection and potential field data in models that illustrate the 2-D crustal structure at key locations on the margin. Despite the limitation on the interpretation imposed by the wide line separation and by sparse data from the upper slope and continental shelf (other than that off Prydz Bay), this synthesis provides a broad tectonic framework on which future detailed studies can be built.

\section{Background}

\section{Physiography}

The continental margin in the study area west of $60^{\circ} \mathrm{E}$ is characterised by a narrow continental shelf (30-70 km wide) and a continental slope that is dominated by spur and canyon topography for $150-250 \mathrm{~km}$ oceanwards from the shelf edge. This spur and canyon topography is the result of a complex interplay of depositional and erosional processes. East of $60^{\circ} \mathrm{E}$, the major controlling factor on the gross margin morphology is the Lambert Glacier, the largest outlet ice stream in East Antarctica, which discharges through Prydz Bay. The continental shelf in this sector is highly variable in width, ranging from $<100 \mathrm{~km}$ on the Mac. Robertson Shelf, west of Prydz Bay, to more than $280 \mathrm{~km}$ in central Prydz Bay, and to about $180 \mathrm{~km}$ to the east of Prydz 


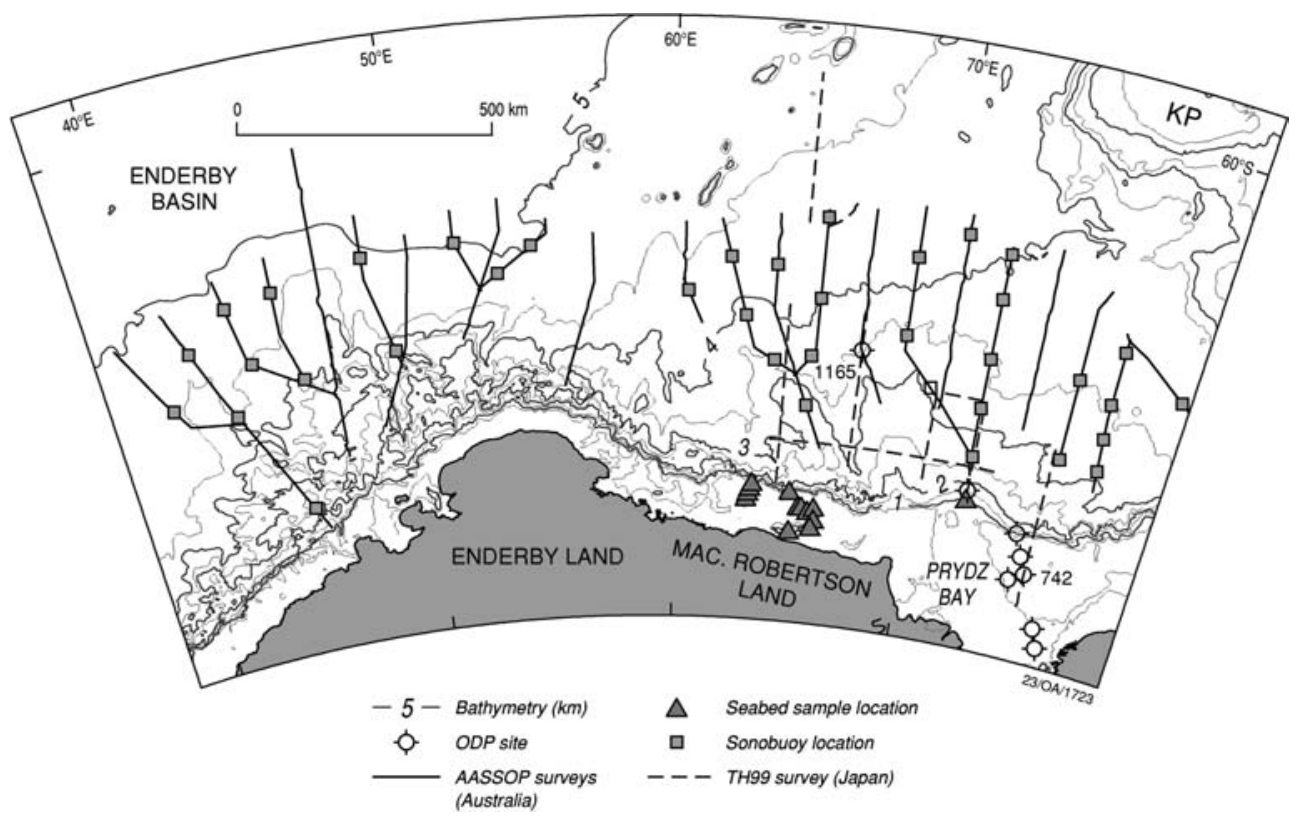

Figure 2. Bathymetry of the margin of Enderby Land. Also shown are the locations of the seismic lines recorded by Australia and Japan from 1999 to 2002, sonobuoy stations recorded by Australia, key seabed samples and Ocean Drilling Program (ODP) sites. KP is Kerguelen Plateau.

Bay. West and east of Prydz Bay, the upper continental slope is steep down to about $3000 \mathrm{~m}$ depth. In contrast, the slope directly offshore from Prydz Bay is more gentle, reflecting a greater buildup of sediments, and the morphology of the margin is dominated by broad, lowrelief fans and valleys that extend radially from Prydz Bay for more than $250 \mathrm{~km}$ into the deep ocean basin.

Oceanward of the margin, the northwestdeepening Enderby Basin reaches depths of more than $5000 \mathrm{~m}$. The basin is bounded by the Princess Elizabeth Trough to the east, by the southern Kerguelen Plateau and Elan Bank of the central Kerguelen Plateau to the northeast and north, by the Kerguelen Fracture Zone and Con$\mathrm{rad}$ Rise to the northwest, and by the Gunnerus Ridge to the west.

\section{Geology}

Information on the nature of the rift- and postrift-phase rocks underlying the margin off Enderby and Mac. Robertson Lands is sparse, being limited to a few dredge and core samples and drilling by the Ocean Drilling Program (ODP). No pre-rift basement rocks have been sampled offshore, and thus the nature of these rocks can only be surmised by extrapolation from coastal outcrops.

The onshore geology is comparatively wellexposed along the coasts and adjacent hinterland of Enderby, Kemp and Mac. Robertson Lands (summarised by Tingey, 1991). The oldest rocks are granulites of the Napier and Rayner Complexes of Enderby Land, which have been dated as Archaean (chronology summarised by Sheraton et al., 1987). Bedrock exposures along the coast of Kemp Land consist mainly of highgrade granulite facies gneisses intruded by, in some cases, Mesoproterozoic to Neoproterozoic charnockite plutons (Tingey, 1991). On the eastern side of Prydz Bay, mainly granulite facies metamorphic rocks ranging in age from Archaean to Mesoproterozoic are exposed in the Larsemann and Vestfold Hills and adjacent islands (Sheraton et al., 1984). In the absence of basement samples from offshore, it is assumed here that basement rocks underlying the continental margin are also Archaean to Proterozoic gneisses that have been intruded by granitoid plutons and mafic dykes.

Coring and dredging by Australian National Antarctic Research Expedition surveys on the 
Mac. Robertson Shelf (Geoscience Australia surveys 901, 149 and 186; O'Brien et al., 1993, 1995; Harris et al., 1997) show evidence of Cainozoic and Mesozoic outcrops on the sea floor. Truswell et al. (1999) described Mesozoic palynomorphs and the setting of the sediments from which they were derived, and Quilty et al. (1999) described Cainozoic material recovered from the area. The distribution of these sediments led Truswell et al. (1999) and O'Brien et al. (2001) to suggest the following geological history:

1. Deposition of sediments in an intracratonic sag or early rift basin during the ToarcianBajocian.

2. Extension and normal faulting from the Callovian to at least the Aptian.

3. Continental shelf sedimentation through the Palaeocene to the late Eocene, possibly continuing until the Middle Miocene.

4. Erosion of the shelf by grounded ice since the Middle Miocene.

Until the mid-Cretaceous, this history is consistent with the geology of the basins of the east coast of India, which, together with fragments of the Kerguelen Plateau, was conjugate to the Enderby Land margin. The Indian margin basins comprise a cratonic phase containing continental and marine rift-phase sediments of Jurassic and Early Cretaceous age, and a post-rift mainly marine section of Late Cretaceous and Cainozoic age (Prabhakar and Zutshi, 1993). Geological and geochemical evidence from the Ocean Drilling Program (ODP) Leg 183 Site 1137 show that Elan Bank, a west-protruding salient on the Kerguelen Plateau, is at least partly of continental origin (Coffin et al., 2000; Nicolaysen et al., 2001; Weis et al., 2001). However, little detail is known of the pre-breakup geology of Elan Bank (and any other continental fragments incorporated into the Kerguelen Plateau) and its precise fit between India and Enderby Land.

ODP Leg 119 drilled sites on the southern Kerguelen Plateau and in Prydz Bay (Barron 1989). One of the latter sites (Site 742) is tied by the Japanese seismic line TH99-35 which is incorporated into a margin transect in this paper. Site 742 reached total depth in Eocene/Oligocene glacial marine sediments. ODP Leg 188 (O'Brien et al., 2001) drilled three sites, of which Site 1165 is tied to our seismic line 228/07, also illustrated here. This site reached total depth in Early
Miocene sediments at $999.1 \mathrm{~m}$ below sea floor. As the total post-rift sedimentary section at the site is approximately $3.3 \mathrm{~s}$ two-way time (TWT) thick (ca. $5 \mathrm{~km}$ ), a large part of the sedimentary section has not been sampled and its composition and age therefore remain speculative.

\section{Geophysical surveys}

The first seismic survey in the region was carried out by Australia in Prydz Bay and on the adjacent continental slope in 1982 (Stagg, 1985). Since then, a number of regional seismic surveys have been carried out in Prydz Bay, on the continental margin and in the Enderby Basin, mainly by Japan and Russia. However, published interpretations of these data are limited. Reports of the data recorded by Japan have generally been limited to preliminary interpretations published shortly after each survey (Mizukoshi et al., 1986; Joshima et al., 2001). Russia (and previously the USSR) have recorded a wide-ranging grid of MCS, seismic refraction and potential field data throughout this region, but published interpretations of these data are scarce (e.g., Leitchenkov et al., 1990; Gandyukhin et al., 2002).

The most relevant Russian publication to our interpretation is that of Gandyukhin et al. (2002). Their interpretation made use of reflection, refraction and potential field data. The principal findings of their study can be summarised as:

- On the shelf basement is usually overlain by $0.5-2.0 \mathrm{~km}$ of sediments. Beneath the outer shelf or upper slope, basement is downfaulted to a depth of about $9 \mathrm{~km}$. The area at the base of the continental slope and beneath the rise is interpreted as extended continental crust with Jurassic rift structures having local relief of $0.3-1 \mathrm{~km}$.

- The boundary between continental and oceanic crust is interpreted mainly on the basis of refraction data and is mapped where upper crust velocities change from $5.9-6.3 \mathrm{~km} \mathrm{~s}^{-1}$ (typical for continental basement) to $5.2-$ $5.5 \mathrm{~km} \mathrm{~s}^{-1}$ (typical for oceanic basalts). While not always clearly defined in the west, in the eastern Enderby Basin this boundary coincides with a 700-800 m step in basement and a highamplitude (350-500 nT) magnetic anomaly, 
interpreted to reflect the contact between strongly magnetised oceanic crust and lessmagnetised continental crust.

Gandyukhin et al. (2002) also published a tectonic elements map for the region that summarises their interpretation of the major crustal boundaries i.e. the basement scarp underlying the shelf edge/ upper slope and the interpreted continent-ocean boundary (COB) -together with an integrated seismic and gravity model extending from the inner continental shelf out to oceanic crust. The seismic lines interpreted in this paper cross both of these boundaries.

\section{Seafloor spreading history}

Recent surveys in the Enderby Basin by Japan (Ishihara et al., 2000), Russia (Gandyukhin et al., 2002) and Australia (Brown et al., 2003) have identified $\mathrm{M}$-series spreading anomalies. In these studies, Ishihara et al. (2000) identified anomalies that included M10N, M4 and M2, while Gandyukhin et al. (2002) interpreted anomalies M11A to M8. In this paper, we use the most recent identification by Brown et al. (2003) of anomalies M10y to M2o. Magnetic spreading anomalies have also been identified off the conjugate margin of east India, where Ramana et al. (1994) interpreted anomalies back to M11, generated at a spreading rate of $3.5 \mathrm{~cm} \mathrm{a}^{-1}$. Banerjee et al. (1995) proposed an alternative model for the Bay of Bengal in which they suggested that the Rajmahal hot spot powered the rifting of India from Antarctica from $117 \mathrm{Ma}$ (Barremian) onwards.

The most recent magnetic anomaly picks off Enderby Land by Brown et al. (2003) were incorporated by Gaina et al. (2003) in a refinement of plate reconstructions in the Indian Ocean. Their new model interprets the spreading rate to be about $4.0 \mathrm{~cm} \mathrm{a}^{-1}$ from the onset of spreading at about $130 \mathrm{Ma}$ (time scale of Gradstein et al., 1994) to chron M4 (126.7 Ma) and then decreased to about $1.6 \mathrm{~cm} \mathrm{a}^{-1}$ until spreading in the Enderby Basin ceased at about $124 \mathrm{Ma}$. At this time, a spreading ridge jump to the east Indian margin transferred the Elan Bank microcontinent to the Antarctic Plate. If this interpretation is correct, then the dating of magnetic anomalies older than M2 in the Bay of Bengal by Ramana et al. (1994) is probably incorrect.
On the basis of magnetic anomaly trends and fracture zones identified in satellite gravity data (Sandwell and Smith, 1997), Gaina et al. (2003) interpreted seafloor spreading in the Enderby Basin to have taken place on a north-northwest azimuth.

\section{Interpretation}

This interpretation is based on the integration of reflection and refraction seismic data and potential field modelling, and is illustrated by reference to example sonobuoy interpretations (Figure 4; Table 1) key reflection seismic transects (Figures 5-9), seismic section details (Figures 10-15), potential field models (Figures 16 and 17) and a map of the interpreted tectonic elements (Figure 18). The locations of the illustrated sonobuoy stations, seismic profiles and potential field models are shown in Figure 3.

\section{Crustal structure from seismic data}

As noted above, the reflection seismic data are the principal data set on which this interpretation is based. These data are both high-resolution and deep-penetrating, and provide excellent resolution of the shallow sedimentary sequences as well as images of the deep crust and upper mantle in the case of oceanic crust.

The reflection seismic interpretation is complemented by modelling of the wide-angle reflection and refraction data recorded from non-reversed expendable sonobuoys. All sonobuoys were modelled using the SIGMA ray-tracing software developed by the Geological Survey of Canada (Seismic Image Software, 1995). A starting model at each sonobuoy station was created by depth-converting the interpreted reflection seismic section using fixed interval velocities estimated from the seismic stacking velocities. The model was then iteratively matched to the sonobuoy picks by adjusting layer velocities and depths, commencing with the shallow sedimentary section. The high quality and deep penetration of the reflection seismic data was invaluable in constraining the geometries of the deeper refractors at many stations, thereby partially offsetting the shortcomings of the stations being non-reversed. Where refracted arrivals were 


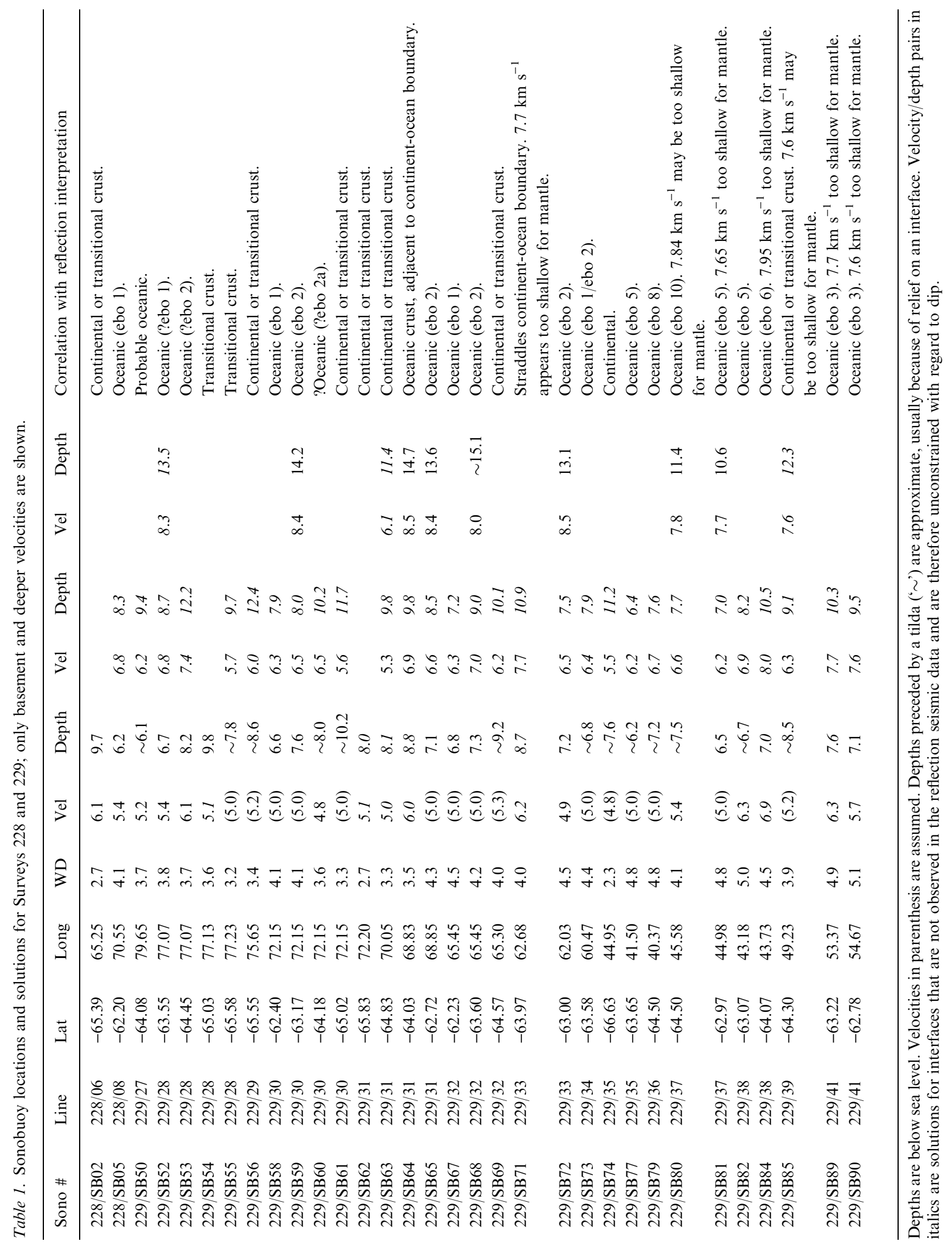


evident in the sonobuoy record, but there was no corresponding interface visible in the reflection data (as was typically the case for oceanic layer 3 ), a velocity boundary was added to the model.

The sonobuoys have been modelled assuming a fixed interval velocity for each layer rather than with velocity gradients. In the case of the sedimentary section, there is no velocity-depth information from wells available for this region and stacking velocities are not sufficiently sensitive at the relevant depths to allow gradients with individual layers to be determined. In the case of the crystalline crust, we acknowledge that some detailed studies have determined velocity gradients for different parts of the crust (see White et al. (1992) for a discussion of this effect in oceanic layers 2 and 3). However, it was decided that introducing complexities through estimated velocity gradients was not justified when the sonobuoys were non-reversed. The result of this simplification of the velocity profile is that layer thicknesses and interface depths will be underestimated. In the case of oceanic crust, White et al. (1992) have shown that this under-estimation can be up to $15 \%$.

The interpreted velocities from basement and the deeper crust and mantle are listed in Table 1 and example interpretations of sonobuoy stations from continental and oceanic crust are illustrated in Figure 4.

\section{Continental margin rift crust}

As with most Antarctic margin seismic surveys, the GA-228/229 and TH99 surveys only provide limited coverage of the continental shelf due to widespread ice coverage. Other than beneath Prydz Bay, the seismic data on the continental shelf suggest that crystalline crust generally lies at shallow depths and has only a thin sedimentary cover. However, as noted above, Truswell et al. (1999) and O'Brien et al. (2001) have inferred the presence of Jurassic-Cretaceous half graben beneath the inner part of the shelf to the west of Prydz Bay. Profiles from western Enderby Land and Mac. Robertson Land (Figures 5a and 6) show that crystalline basement is downfaulted beneath the upper continental slope to depths of 7-8 s TWT (ca. 8-10 km) across several major faults. As the GA-228/229 and TH99 seismic data consistently show the presence of a very thick sedimentary section beneath the continental slope along this margin, we interpret the shelf edge and upper slope to generally coincide with a major basement fault zone and the landward limit of a major margin-parallel sedimentary basin (Figure 18). Russian seismic profiles in the area have been similarly interpreted (e.g., Figures 3 and 4 of Gandyukhin et al., 2002). Golynsky et al. (1996) also interpreted a highamplitude magnetic anomaly west of $50^{\circ} \mathrm{E}$ (their

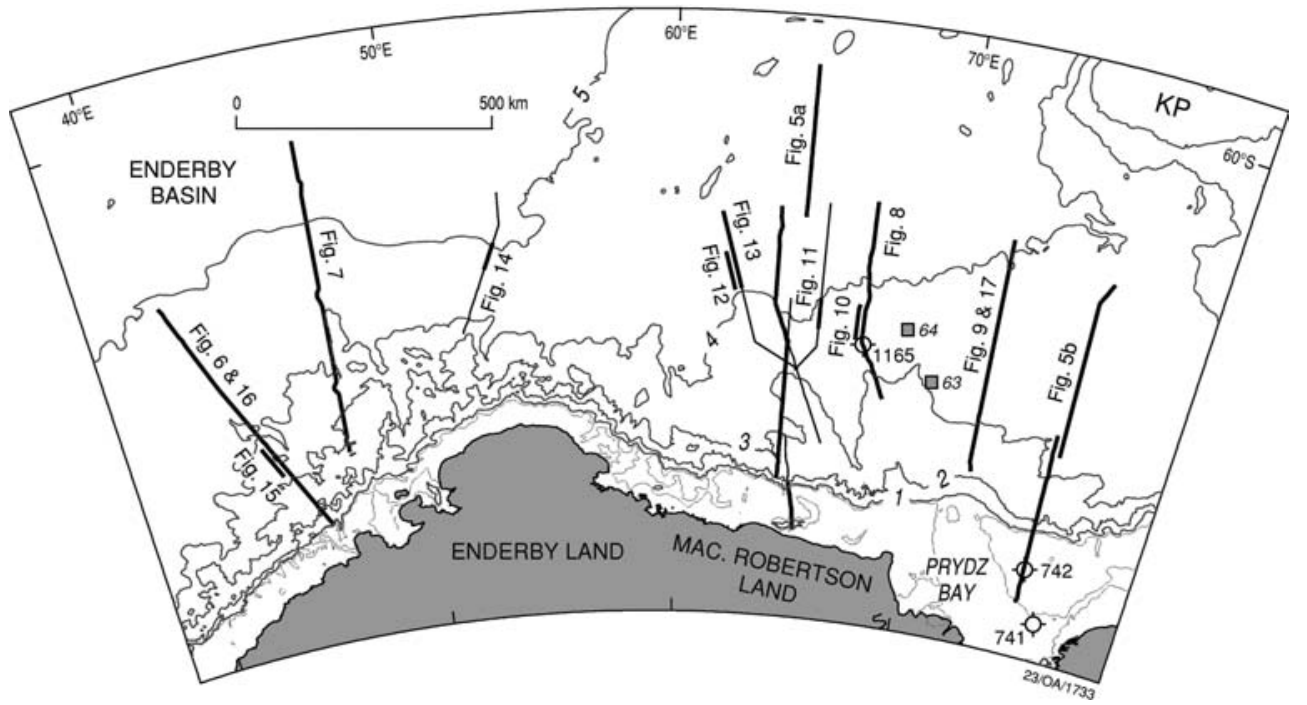

Figure 3. Locations of sonobuoy interpretations (squares annotated as 63 and 64) illustrated in Figure 4 and seismic profiles and potential field models that are illustrated in Figures 5-17. KP is Kerguelen Plateau; 742 and 741 are locations of ODP Sites 741 and 742 . 

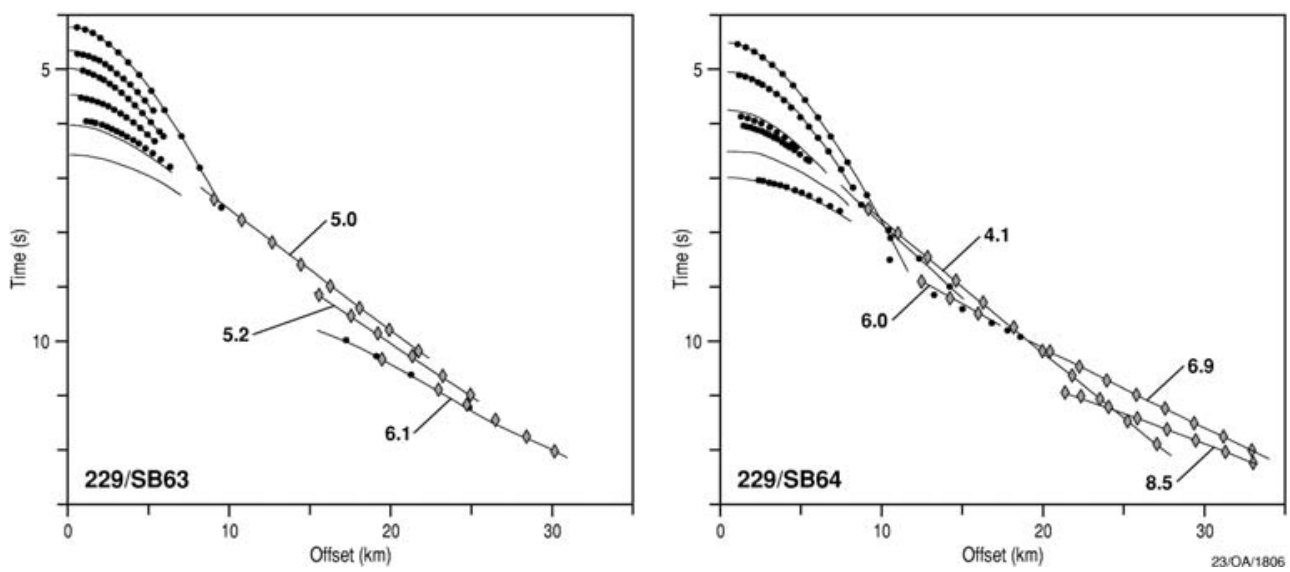

Figure 4. Examples of sonobuoy interpretations from continental/transitional crust (229/SB63, left) and oceanic crust (229/SB64, right). These sonobuoys were recorded on the same seismic line and are approximately $100 \mathrm{~km}$ apart. Recorded events are shown as solid lines. Circles indicate modelled wide-angle reflections; diamonds indicate modelled refractions. Numbers indicate refractor velocities $\left(\mathrm{km} \mathrm{s}^{-1}\right)$.

'Antarctic Continental Margin Magnetic Anomaly'), at approximately the same location as our shelf-slope basement fault zone, as a continentalscale crustal discontinuity formed during margin breakup.

Structuring beneath the outer edge of Prydz Bay is further complicated by the presence of the major N-S trending Prydz Bay Basin (Figure 18), interpreted by Stagg (1985) to be a failed rift at a triple or four-armed junction that contains at least $5 \mathrm{~km}$ of Permian and younger sedimentary rocks deposited on the underlying Lambert Graben. The Cretaceous and Cainozoic section shown in Figure $5 \mathrm{~b}$ has been dated through a direct tie to ODP site 742 and via other seismic lines to ODP Site 741. Beneath this section, possible crystalline basement is interpreted at a depth of about $2.5 \mathrm{~s}$ TWT (ca. $3.5 \mathrm{~km}$ ) approximately $60 \mathrm{~km}$ landwards of the shelf break. Beneath the continental slope, a minimum of $8 \mathrm{~km}$ of sedimentary rocks is observed, indicating that basement is downfaulted by at least $6 \mathrm{~km}$. However, the strong and ubiquitous seabed multiples beneath the shelf and upper slope preclude direct seismic imaging of the faulting.

Beyond the shelf-slope fault zone, there is a belt of deeply subsided and probably rifted crust that varies in width from approximately $300 \mathrm{~km}$ offshore from Prydz Bay and eastern Enderby Land, to $150-200 \mathrm{~km}$ off central and western Enderby Land. Basement in this area is not welldefined in the reflection data, probably due to two main causes. Firstly, the seismic signal is degraded by the very large thickness of sedimentary section overlying basement beneath the margin, which ranges from $6 \mathrm{~km}$ to more than $8 \mathrm{~km}$ thick. Secondly, while the Enderby-Mac. Robertson Land margin is classified as 'non-volcanic' on the basis of the absence of seaward-dipping reflector sequences (SDRS), it is still likely that there are igneous rocks within and overlying basement. These rocks have probably blurred the seismic imaging of any basement fault blocks. The timing of volcanic emplacement is unclear; it might be of pre-breakup age or it could be related to the mantle plume which generated large parts of the Kerguelen Plateau.

Seven Survey GA-228/229 sonobuoys in this area recorded refracted arrivals from the main crustal layer, mainly offshore from Mac. Robertson Land (Table 1). The interpreted velocities range from 5.7 to $6.3 \mathrm{~km} \mathrm{~s}^{-1}$ (average $6.1 \mathrm{~km} \mathrm{~s}^{-1}$ ), which is consistent with the presence of continental crust. No higher velocities were recorded at these sites, probably due to the large thickness of overburden, the size of the seismic source used $(601)$ and the limited recording range of the sonobuoys (generally less than $35 \mathrm{~km}$ ). While Russian surveys have recorded many refraction stations in this region, reporting of the results is limited. Gandyukhin et al. (2002) reported basement velocities of $5.9-6.3 \mathrm{~km} \mathrm{~s}^{-1}$ from this deeply subsided crust; they also showed velocities of $6.0-6.2 \mathrm{~km} \mathrm{~s}^{-1}$ in the crustal section 


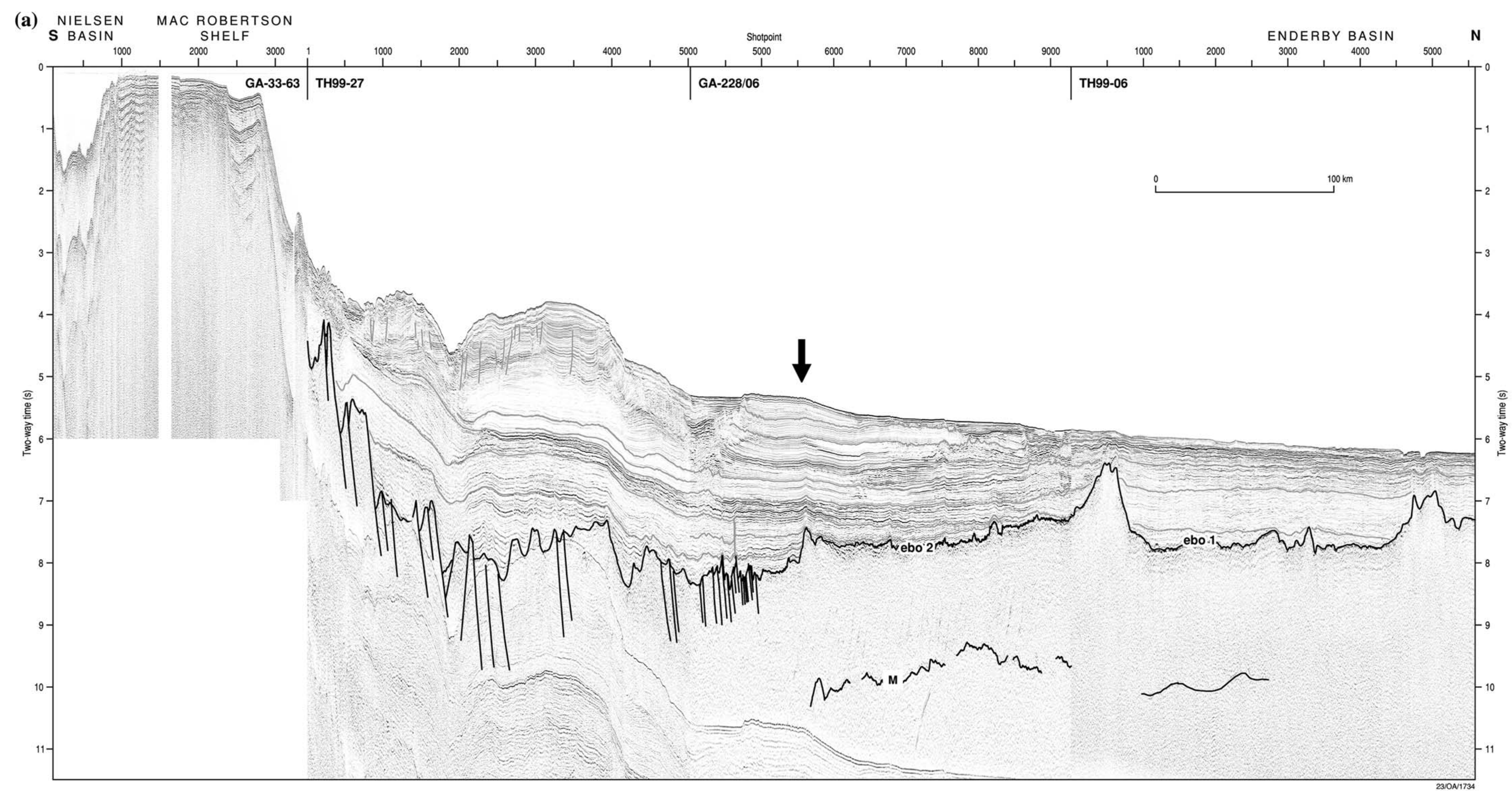

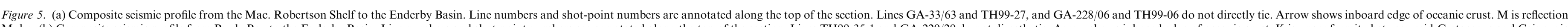

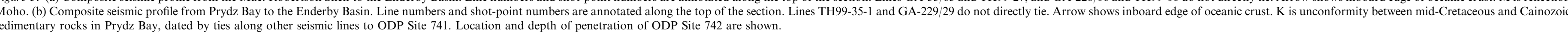




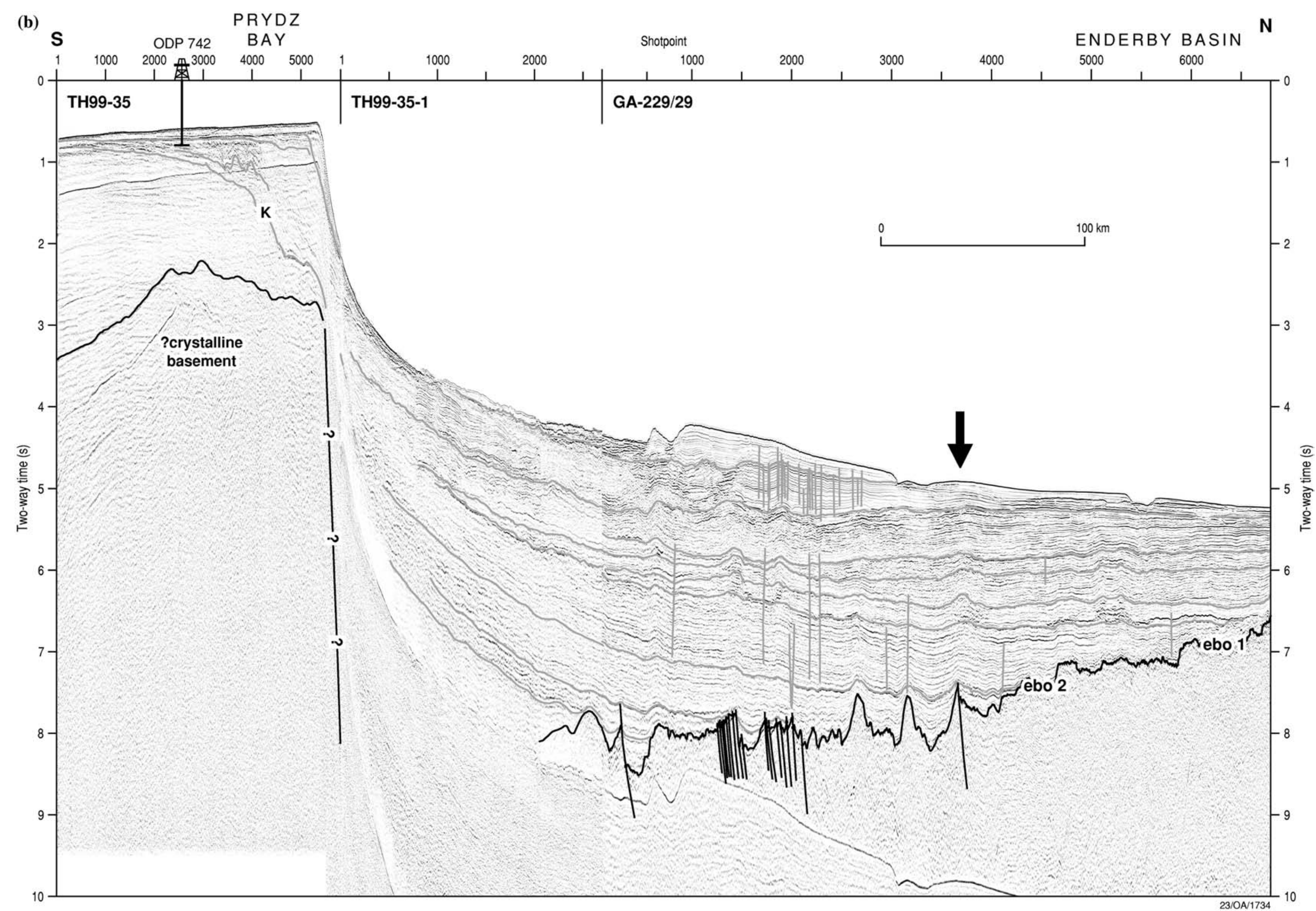

Figure 5. (Continued). 
that they model from seismic and gravity data. Largely on the basis of the distribution of crustal velocities, they further interpreted the transition from continental to oceanic crust to be located at approximately $64^{\circ} \mathrm{S}$ offshore from Mac. Robertson Land.

To date, lineated magnetic anomalies that could be identified as the product of seafloor spreading have not been interpreted from this zone of crust. Brown et al. (2003) report that the southern limit of identified seafloor spreading magnetic anomalies is marked by an approximately $\mathrm{E}-\mathrm{W}$ trending, prominent, high-amplitude magnetic anomaly (their 'MacRobertson Coast Anomaly', or MCA) flanked to the south by a magnetic anomaly low. The location of this anomaly correlates closely with the change in basement seismic character that is noted by an arrow in Figures 5a, 8 and 9.

After integrating the seismic reflection character, crustal velocities and the distribution of lineated magnetic anomalies, we are therefore confident in interpreting this zone of rifted crust as being primarily of continental origin. This interpretation is discussed further in this paper in the section detailing the potential field modelling.

\section{Oceanic crust}

Oceanward of the belt of deeply subsided, probable continental crust, the basement is interpreted as unequivocally oceanic on the basis of its reflection seismic character and velocity structure. This crust is particularly notable for a range of distinctive seismic reflection characters, and the consistency of those characters over broad areas, suggesting that the crust is divided into a number of discrete spreading compartments. There is also a degree of correlation of the broad crustal types with variations in the crustal velocity profile. The different crustal types are annotated on the seismic sections illustrated here, and the characteristics of the identified types are listed in Table 2. Along the margin, ocean crust can be split into three distinctive zones: from $58^{\circ} \mathrm{E}$ to $76^{\circ} \mathrm{E}$; from $52^{\circ} \mathrm{E}$ to $58^{\circ} \mathrm{E}$; and west of $52^{\circ} \mathrm{E}$.

The sector from $58^{\circ} \mathrm{E}$ to $76^{\circ} \mathrm{E}$ contains the most distinctive Enderby Basin oceanic crustal type, ebo 2 ('ebo' for 'Enderby Basin oceanic'), characterised by
- A generally smooth, high-amplitude reflection from the basement surface (horizon ebo 2; Figure 10).

- Short, north-dipping reflectors, probably indicating lava flows, in the uppermost few hundred metres of basement (Figure 10).

- A layer of seismically transparent crust, approximately $0.6 \mathrm{~s}$ TWT $(\mathrm{ca} 1.5 \mathrm{~km})$ thick, underlying the upper crustal flows (Figure 10). There are hints of sub-horizontal reflections within this zone (e.g., Figure 11, at about $8.5 \mathrm{~s}$ TWT).

- Highly reflective lower crust, averaging $1.5 \mathrm{~s}$ TWT (ca $5 \mathrm{~km}$ ) thickness, with both northand south-dipping planar reflectors (Figures 10-12). The apparent dip of these reflectors averages $30^{\circ}$, and the dip and distribution of individual reflectors is very regular.

- Oceanic layer 3 refraction velocities from sonobuoys averaging $6.7 \mathrm{~km} \mathrm{~s}^{-1}$ (range from 6.5 to $7.0 \mathrm{~km} \mathrm{~s}^{-1}$ ).

- A very strong sub-horizontal reflection at about $10 \mathrm{~s}$ TWT. This reflector has very high continuity in some places (e.g., Figure 11) but can also be discontinuous (e.g., Figure 12). Sonobuoy solutions from several lines (e.g., Figure 9) show velocities greater than $8 \mathrm{~km} \mathrm{~s}^{-1}$ at about this depth, indicating that this reflection is from Moho. In some areas, the dipping reflectors in the overlying crust sole out on to the Moho (Figure 11), but elsewhere they appear to disrupt Moho and continue into the upper mantle (Figure 12). There is also some long-wavelength relief on Moho. For example, in Figure 9 it shallows from 10 to $9.5 \mathrm{~s}$ TWT (ca $1.6 \mathrm{~km}$ ) over a distance of about $25 \mathrm{~km}$, before deepening again northwards.

The ebo 2 crust is approximately rectangular in map view, extending for about $900 \mathrm{~km}$ along the margin, from the eastern side of Prydz Bay west to central Enderby Land, and for 150$200 \mathrm{~km}$ orthogonal to the margin (Figure 18). The eastern boundary is indistinct, possibly due to thermal and volcanic overprinting from the Kerguelen plume (Coffin et al., 2000). In contrast, the western boundary at approximately $58^{\circ} \mathrm{E}$ is relatively sharply defined (albeit by data along widely separated lines), probably by a fracture zone.

A further distinctive characteristic of this sector is the presence of strong high-continuity 


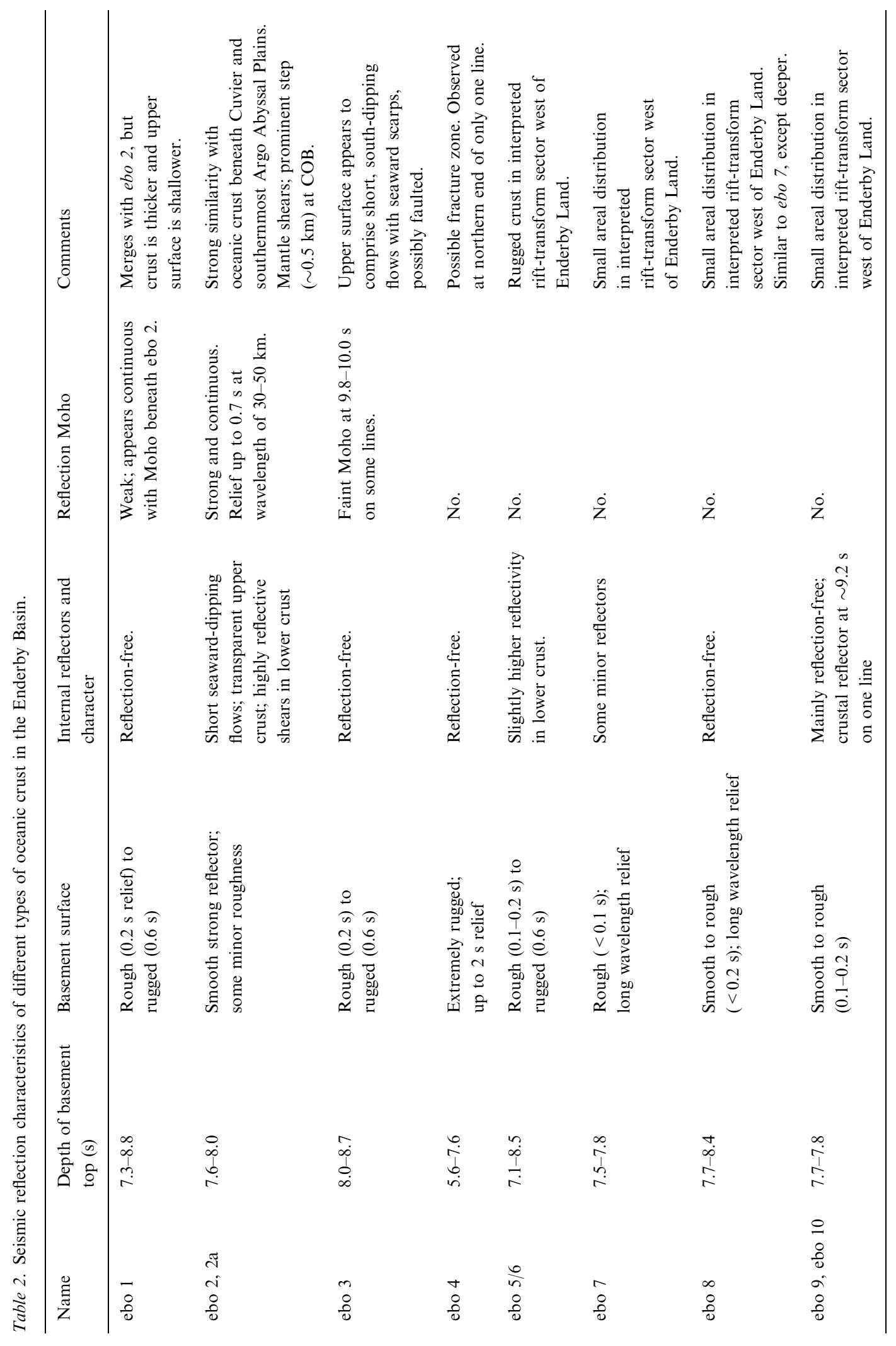




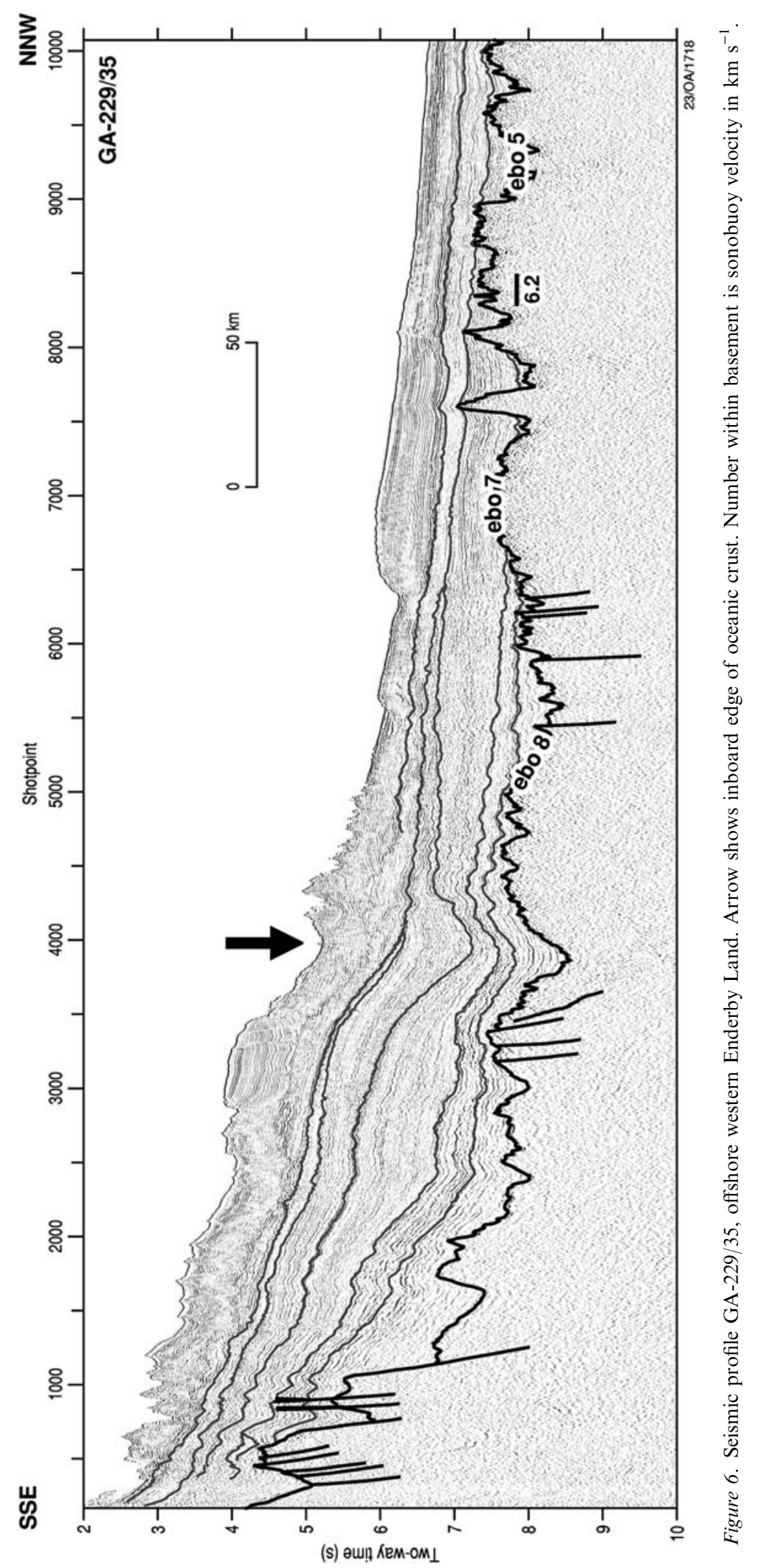




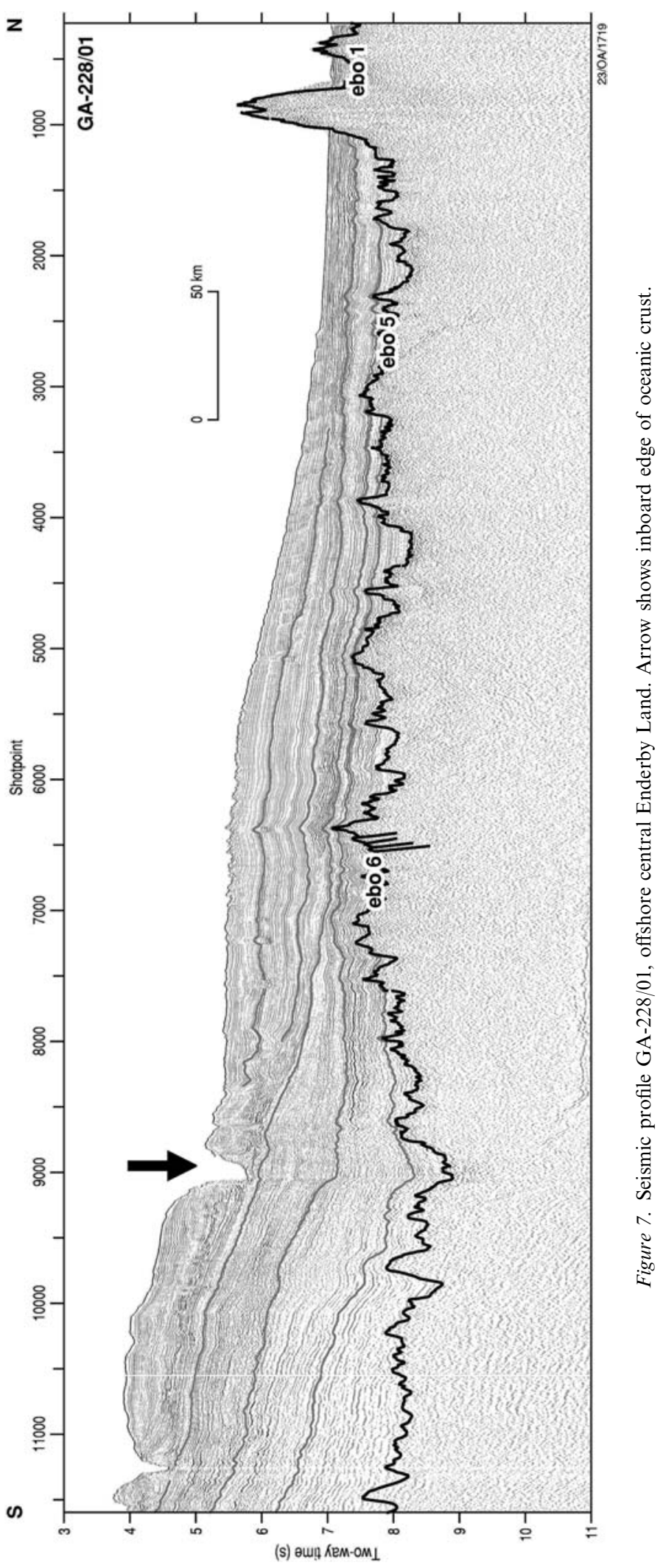




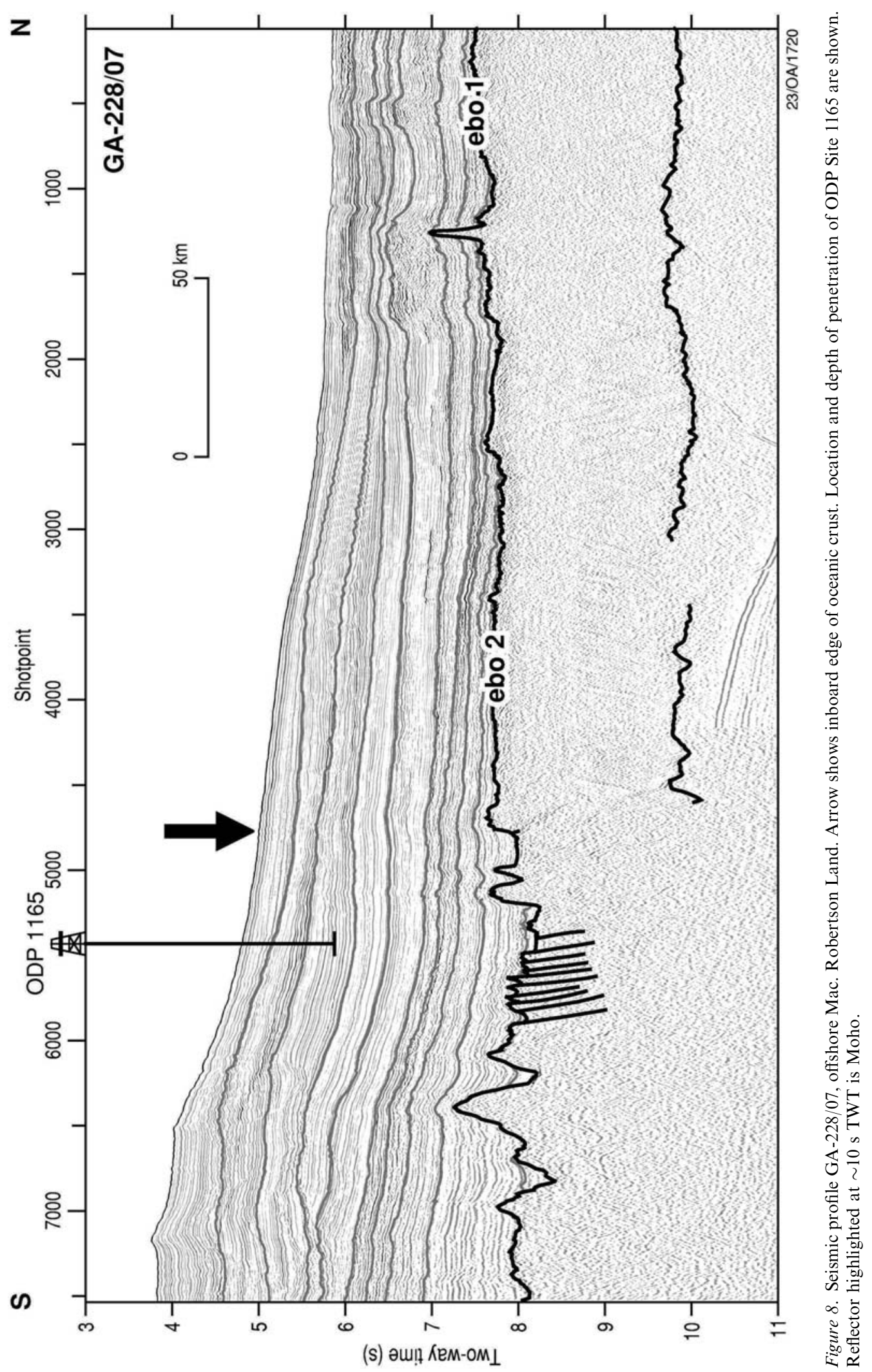




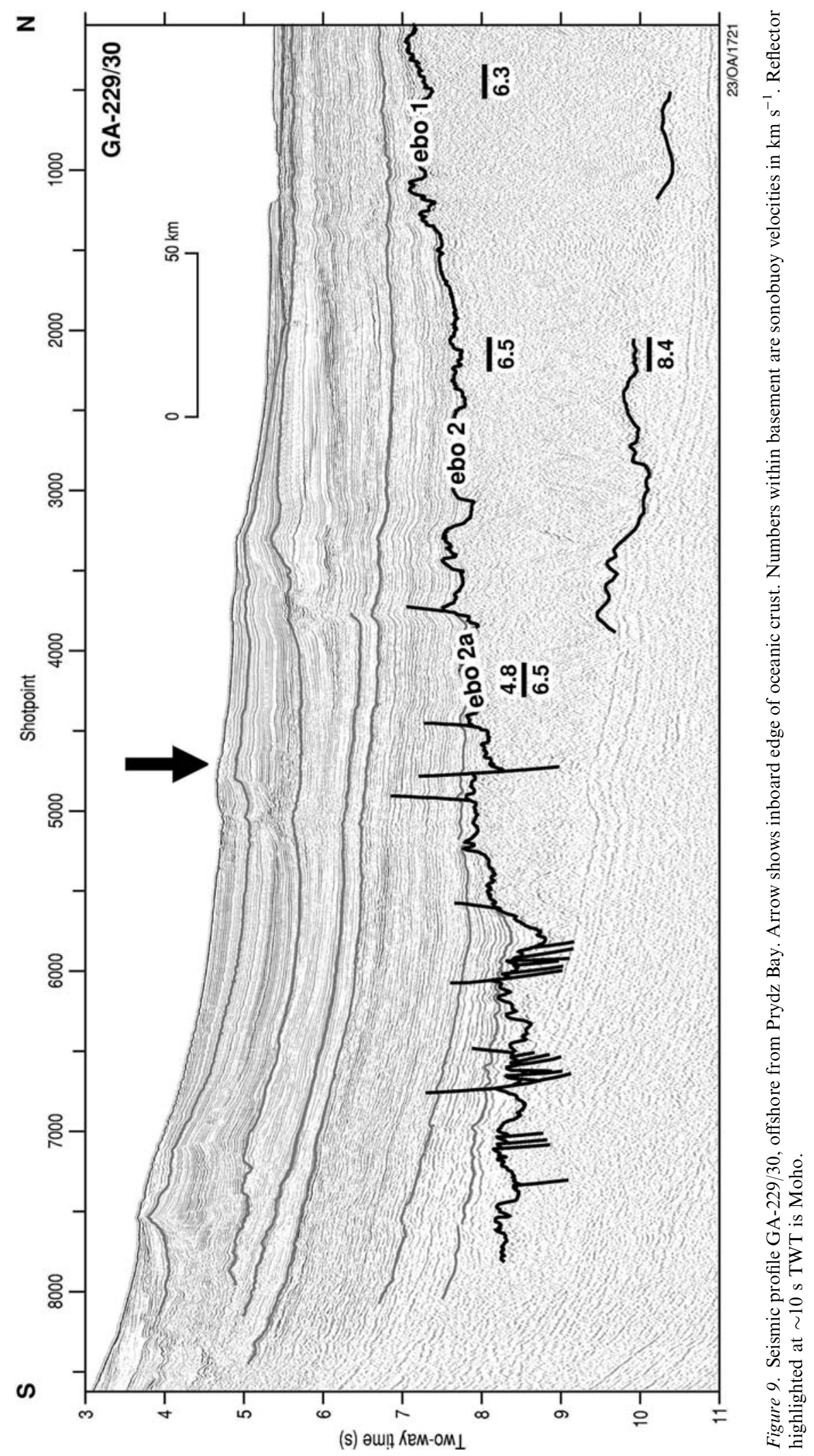




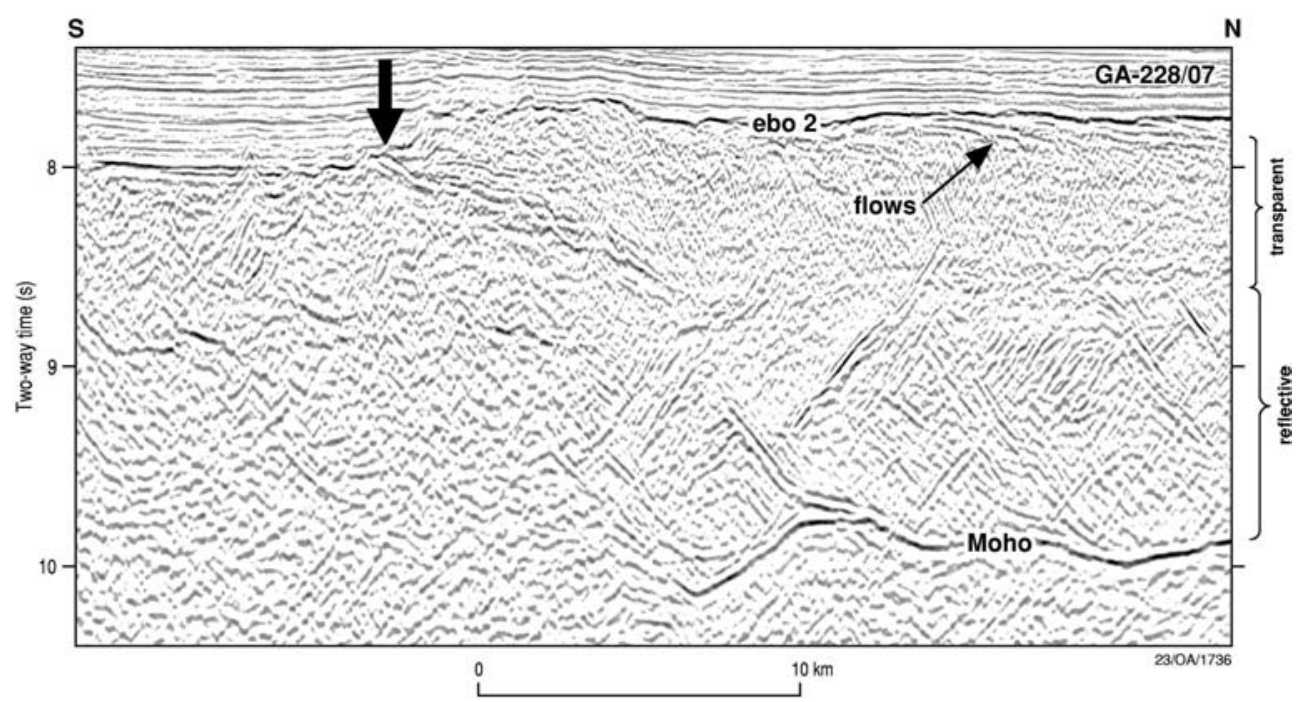

Figure 10. Seismic detail from line GA-228/07 showing the interpreted continent-ocean boundary zone east of $58^{\circ} \mathrm{E}$ (continental/ transitional crust to the south). In particular, note the step up from continental/transitional crust on the left to oceanic crust on the right, and the abrupt southwards termination of reflection Moho beneath the inboard edge of oceanic crust at $\sim 10 \mathrm{~s}$ TWT. Note also the horizontal partitioning of the oceanic crust into a thin upper layer of short, seward-dipping flows; semitransparent upper-middle crust; lower, highly-reflective crust; and high-amplitude, continuous reflection Moho.

dipping reflectors in the upper mantle (e.g., at 10-11 s TWT in Figures 12 and 13). These reflectors are observed on four adjacent lines for approximately $300 \mathrm{~km}$ along-strike on the margin. These reflections are only observed beneath ebo 2 crust, which suggests that they are perhaps related to the spreading processes that account for this very unusual crust. In each example, the reflector dips at $20-30^{\circ}$ towards the continent and can be traced to at least $8 \mathrm{~km}$ depth below Moho. In the east, this reflector appears to bifurcate from the reflection Moho, while to the west (e.g., Figure 12), it appears to be continuous with strong reflectors in the lower oceanic crust. The amplitude of this reflection is comparable to the amplitude of the strongest Moho reflections. At

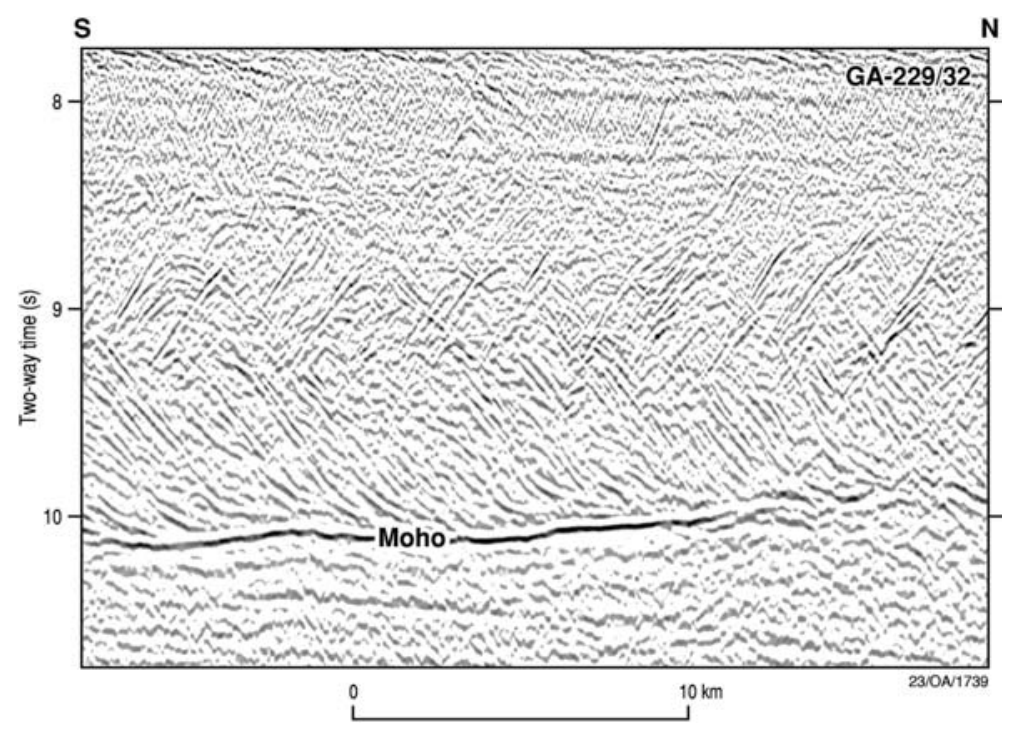

Figure 11. Seismic detail line GA-229/32 showing highly reflective lower oceanic crust (below $~ 8.8 \mathrm{~s}$ TWT) underlain by highly continuous reflection Moho at $10 \mathrm{~s}$ TWT. The deepest reflections in the crust sole out on to the Moho reflection. 


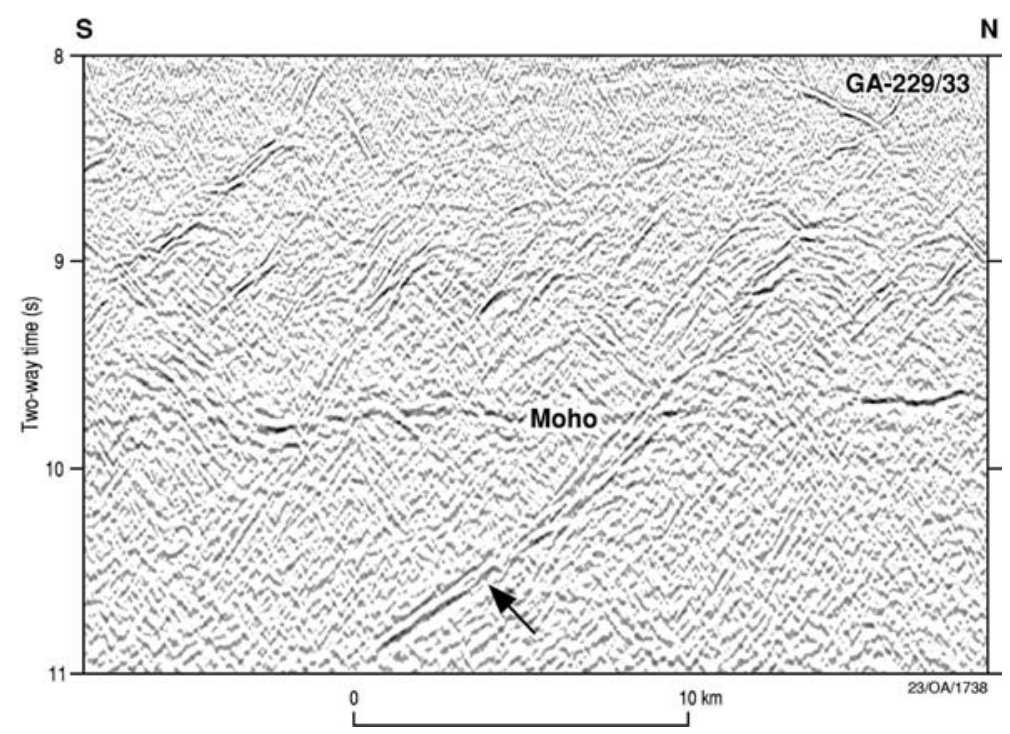

Figure 12. Seismic detail line GA-229/33 showing reflective lower oceanic crust underlain by a discontinuous reflection Moho at about $9.8 \mathrm{~s}$ TWT. The south-dipping reflector in the upper mantle (arrow) may be related to dipping reflectors in the overlying crust.

present, we see no obvious explanation for these mantle reflections, and the high-amplitude is particularly difficult to explain, as it would require large velocity contrasts in the upper mantle.

To the north, the distinctive ebo 2 crust merges with the less distinctive ebo 1 crust (Figure 13). On the basis of the limited seismic data available, ebo 1 crust appears to characterise much of the eastern Enderby Basin, between
Mac. Robertson Land and Elan Bank of the Kerguelen Plateau to the north. In comparison to the ebo 2 crust, the ebo 1 crust is largely devoid of internal reflections, although there are low-continuity, low-amplitude reflections that appear to be continuous with reflection Moho in the ebo 2 sector (Figure 13). The upper surface of the crust shallows by about $1 \mathrm{~km}$ in the transition from ebo 2 to ebo 1 and the total crustal

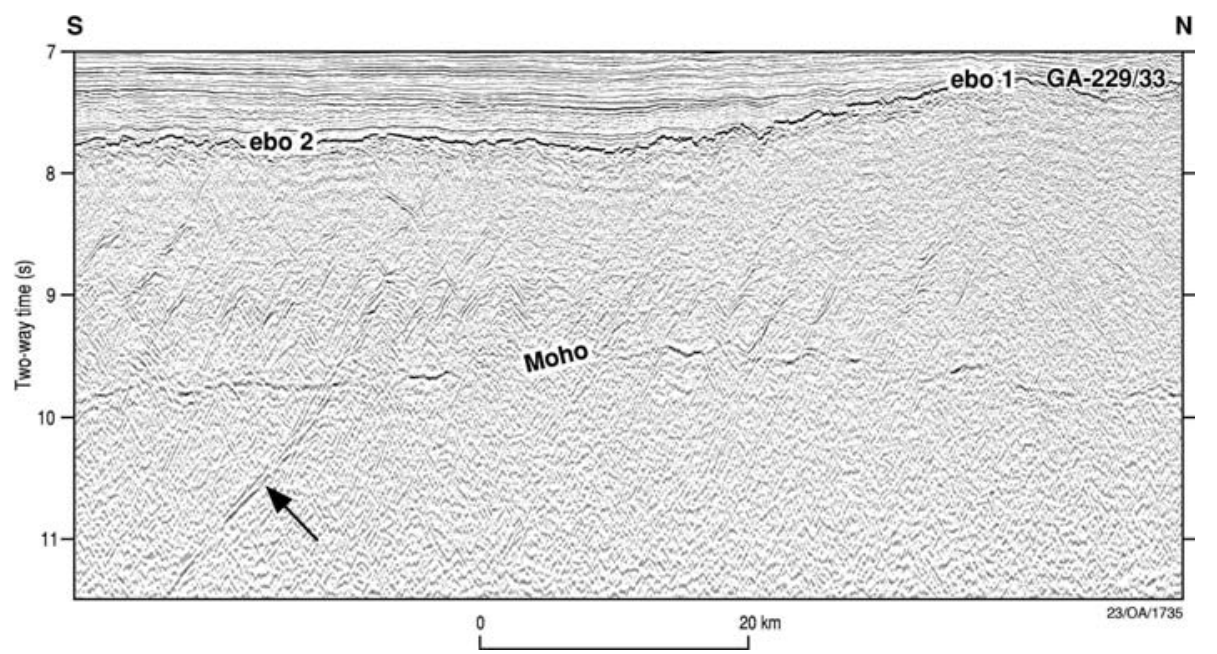

Figure 13. Seismic detail from line GA-229/33 showing oceanic basement types ebo 1 and ebo 2. ebo 2 is at a depth of approximately $7.8 \mathrm{~s}$ TWT; the crust below $\sim 8.5 \mathrm{~s}$ TWT is highly reflective and reflection Moho is strong and continuous. ebo 1 is considerably shallower ( $7.3 \mathrm{~s}$ TWT; the underlying crust is much less reflective and reflection Moho is weaker and less continuous. Note also the south-dipping upper mantle reflections (arrow) at the left-hand end of the profile. 


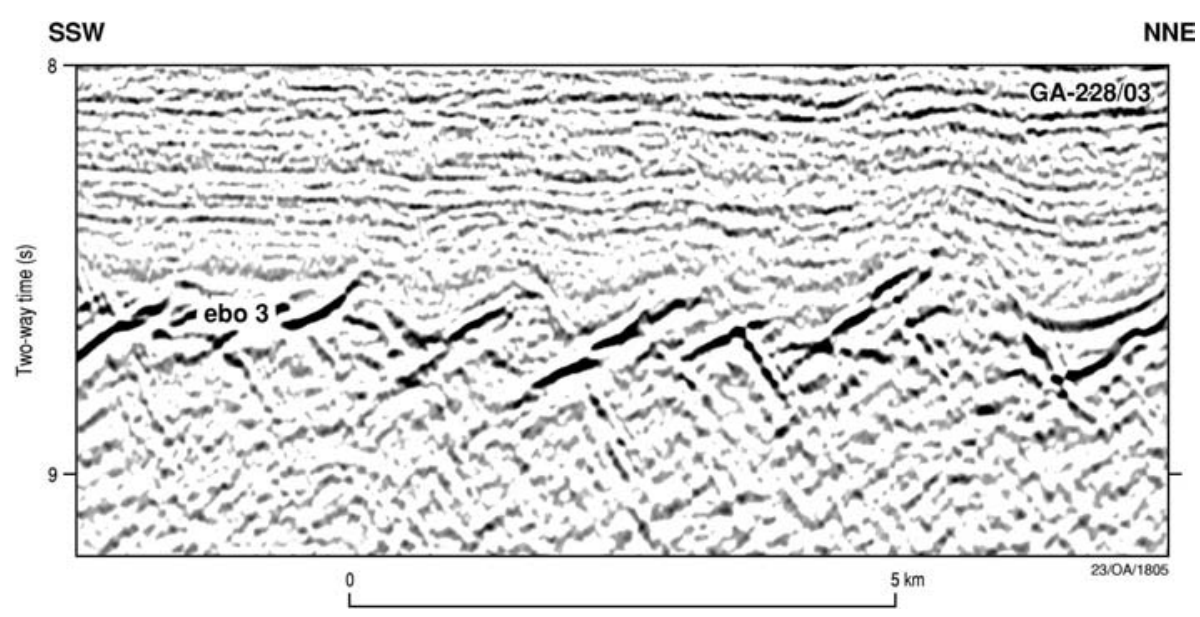

Figure 14. Seismic detail from line GA-228/03 showing the basement type ebo 3. The depth of 8.5-8.7 s TWT for this basement type is significantly deeper than other basement types in the Enderby Basin, and is comparable to the depth of the Jurassic oceanic crust beneath the Argo Abyssal Plain off northwest Australia. Note also the characteristic form of the basement surface, with short, landward-dipping ?volcanic flows with sharp scarps at their oceanward terminations.

thickness increases by about $1.5 \mathrm{~km}$. Taken together, these character and thickness variations indicate a significant change in spreading parameters (spreading rate and magma volume) at this time. Only two sonobuoy stations were recorded on the ebo 1 crust; neither of these indicates a significant change from the velocity profile in the ebo 2 crust.
The narrow sector from $52^{\circ} \mathrm{E}$ to $58^{\circ} \mathrm{E}$ (offshore central Enderby Land) is characterised by a fragment of much deeper oceanic crust (ebo 3; Figure 14). The upper surface of basement is at 8-8.7 s TWT depth, approximately $0.5 \mathrm{~s}$ (ca. $0.8 \mathrm{~km}$ ) deeper than the crust immediately to the east. The basement surface is dominated by short, landward-dipping volcanic flows with

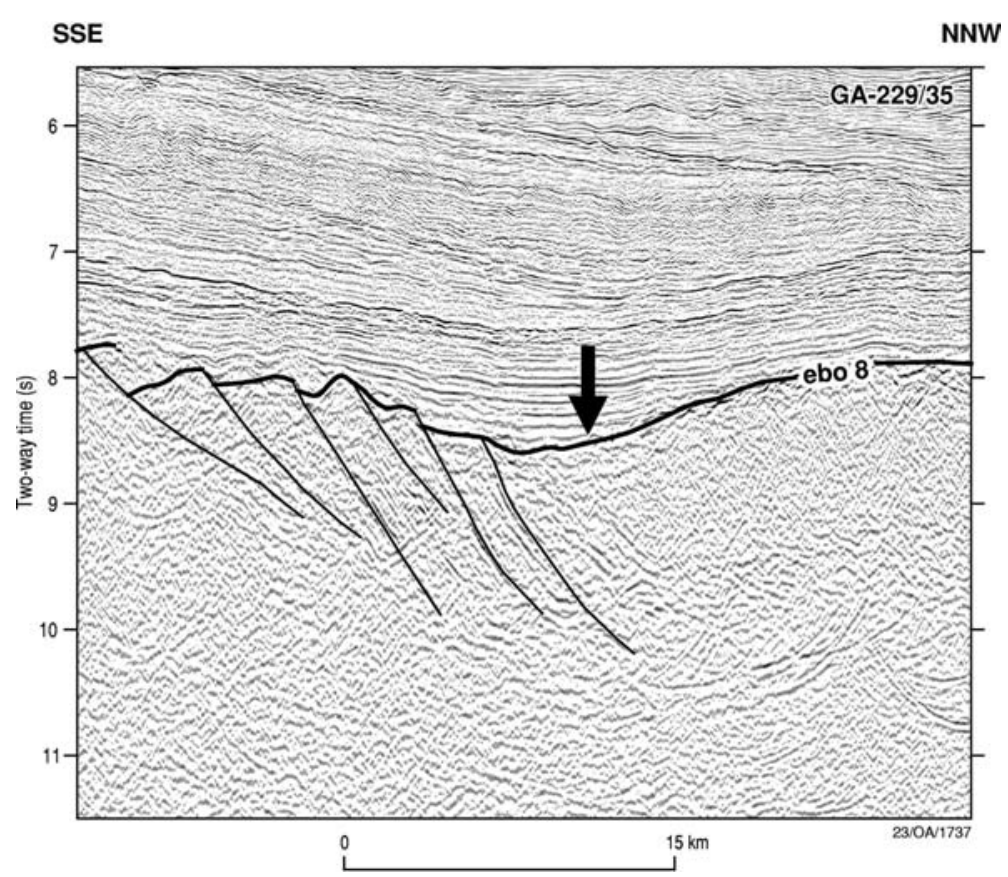

Figure 15. Seismic detail line from line GA-229/35 showing an example of the interpreted continent-ocean boundary west of $58^{\circ} \mathrm{E}$. 
distinct scarps on their oceanward flanks. The anomalous basement depth suggests that this crust may be a remanent of an older phase of seafloor spreading. The depth is very close to that recorded for the Late Jurassic crust of the Argo Abyssal Plain off northwestern Australia (see figure 4 in AGSO North West Shelf Study Group, 1994), and we speculate that this may also be the approximate age of the ebo 3 crust.

In the sector west of about $52^{\circ} \mathrm{E}$ (western Enderby Land), the character of oceanic crust becomes much more varied (types ebo 4 to ebo 10). The wide line spacing does not permit accurate spatial delineation of these crustal types, but their variability may be a function of the inferred mixed rift/transform setting of this part of the margin that is implied by the orientation of crustal elements summarised in Figure 18. The general characteristics of these crustal types include:

- An upper surface that varies from rough (e.g., ebo 7 and ebo 8; Figures 6 and 15) to extremely rugged (relief of up to $1 \mathrm{~km}$; e.g., ebo 5 , in Figure 6) at a range of wavelengths from a few kilometres to $20 \mathrm{~km}$.

- Long wavelength undulations in the basement surface (ca. $100 \mathrm{~km}$; e.g., ebo 7 and ebo 8; Figures 6 and 15).

- Generally reflection-free internal crustal character (Figures 6, 7 and 15). While there is sometimes a slightly increased level of reflectivity in the lower crust, there are few coherent reflections.

- No distinct reflection Moho.

There appears to be a significant difference in the velocities in the deep crust or uppermost mantle between the eastern and western sectors. Whereas mantle velocities in the east are uniformly high (average $8.4 \mathrm{~km} \mathrm{~s}^{-1}$ from six stations), there are no unequivocal mantle velocities of $>7.9 \mathrm{~km} \mathrm{~s}^{-1}$ in the western sector. Although one sonobuoy in this sector gave a velocity of $7.95 \mathrm{~km} \mathrm{~s}^{-1}$, this came from a depth of about $10.5 \mathrm{~km}$; as basement lies at about $7 \mathrm{~km}$ depth, this is probably too shallow to be coming from Moho. Four other sonobuoy stations provided velocities of $7.6-7.8 \mathrm{~km} \mathrm{~s}^{-1}$ at depths that give overlying crustal thicknesses of approximately $4 \mathrm{~km}$. Again, these velocities are unlikely to derive from Moho, unless either there has been extensive alteration of the lower oceanic crust or else closely-spaced transforms have produced crust that is overall thinner than average.

Alternatively, the low western sector velocities could be due to all the sonobuoys being shot down-dip with respect to the $7.6-7.8 \mathrm{~km} \mathrm{~s}^{-1}$ refractor (no reflections at this depth were observed to constrain the models).

\section{Potential field modelling}

\section{Approach}

Potential field modelling was designed to quantitatively validate time-based interpretations of significant seismic profiles against coincident potential field data, with the objective of enhancing understanding of the margin crustal framework, and particularly the relationship between extended continental and oceanic crust. This was done by synthesising migrated depthconverted seismic reflection images, and their interpretations, with density data derived from conversion of seismic refraction and stacking velocities. The gravity and magnetic fields of these petrophysically-attributed geometric models were then concurrently forward-modelled in 3-D, by giving the sections limited strike extents (see below). Limited information on magnetic physical properties was derived from analysis of dredge samples at analogue sites in the Southern Ocean; however, the magnetic properties remain the least constrained part of the validation process.

The crooked line acquisition geometry of the seismic reflection surveys was accommodated by modelling the data in 3-D, rather than by projecting onto a common datum. Models have been continued out of the plane of the section for distances up to $125 \mathrm{~km}$ in both directions, where regional strike allows. Because the geological information is limited out of the plane, this approach is equivalent to ' $2.5-\mathrm{D}$ ' methods that calculate the potential field anomalies in 2-D assuming 'infinite' strike lengths.

The geometry of the starting model was controlled by depth-converting the reflection seismic interpretation using stacking velocities computed during the seismic processing. The stacking velocities were smoothed using a 5-point filter, with the degree of smoothing being increased with the depth below seabed in order to minimise the instability of the stacking velocities with increasing depth. 
Initial density estimates for the sedimentary section were derived by conversion of stacking velocities. In the deeper section, where stacking velocities are less stable, density estimates were derived from refraction velocities interpreted in sonobuoy records. These velocities were converted to densities using the equation of Ludwig et al. (1970).

This method was designed only to produce a set of starting parameters for the initial forward model, as the densities are perturbed during modelling and inversion. As the geometry was generally well-constrained by the reflection seismic data down to at least basement depths (and sometimes down to Moho beneath oceanic crust), the main unknowns in the modelling were the densities and magnetic parameters of the bodies and the geometries of bodies in the deep crust.

The modelling also made the following general assumptions:

- Background density contrast of model is $2.67 \times 10^{3} \mathrm{~kg} \mathrm{~m}^{-3}$, suitable for modelling significant thicknesses of continental crust.

- Body responses are modelled in their correct $x, y$ and $z$ locations, not projected into a plane. The solutions are 3-D analytic for polyhedra, based on the algorithms of Coggon (1976) and Lee (1980).

- Calculations do not account for sphericity of the earth over the distances of the baselines. Given the noise envelope of $\sim 10 \mu \mathrm{m} \mathrm{s}^{-2}$, and the dynamic range of the data (typically $\left.\sim 550 \mu \mathrm{m} \mathrm{s}^{-2}\right)$, these errors $\left(\sim 30 \mu \mathrm{m} \mathrm{s}^{-2}\right)$ are not considered significant.

- In the absence of detailed palaeomagnetic core measurements to determine the absolute strength and direction of remanent vectors, magnetic remanence was modelled by giving each body an apparent Konigsberger Ratio ( $=$ Remanent Field/Induced Field) between 0 and 2. No direction of remanence was specified. This procedure assumes that any body with a high apparent Konigsberger Ratio must have a significant component of remanent magnetisation opposing the present-day geocentric axial dipole inducing field.

Although only two models from Enderby and Mac. Robertson Lands are illustrated in this paper, a total of five lines have been modelled to a consistent level of detail (Stagg et al., 2005). All models show a strong structural consistency along the margin, and the lines that are illustrated here (lines GA-229/35 and GA-229/30; Figures 16 and 17) are considered to be representative.

\section{Potential field datasets}

\section{Gravity data}

The densely sampled ship-track gravity data are 1967 Geodetic Reference System Free Air Anomalies at mean sea level. These data were smoothed during onboard acquisition, using a 3min RC filter on averaged one-second data. The data were subsequently meter, drift, tide and Eötvös corrected, and then further low-pass filtered to reduce high frequency signals and noise. The estimated final RMS noise envelope of the data is $5-10 \mu \mathrm{m} \mathrm{s}^{-2}$.

The gravity profile for line GA-229/35 displays a second-order (polynomial) regional field, that increases from $\sim 0 \mu \mathrm{m} \mathrm{s}^{-2}$ at the southern end of the line to $\sim 250 \mu \mathrm{m} \mathrm{s}^{-2}$ at about shot-point (SP) 4500 , then decreases to $\sim 200 \mu \mathrm{m} \mathrm{s}^{-2}$ at the northern end of the line (Figure 16). Three major gravity highs are superimposed on the regional trend. These have amplitudes of up to $200 \mu \mathrm{m} \mathrm{s}^{-2}$ peakto-peak (ptp), and are located between SP 1000 and 3500 , over clearly imaged continental crust. A major negative excursion of $\sim-420 \mu \mathrm{m} \mathrm{s}^{-2} \mathrm{ptp}$, occurs near the southern end of the line.

The base level of the gravity field in line 229/ 30 is approximately $50 \mu \mathrm{m} \mathrm{s}^{-2}$. The regional field is an order 2 polynomial field that decreases from $\sim 70 \mu \mathrm{m} \mathrm{s}^{-2}$ in the south to $\sim-45 \mu \mathrm{m} \mathrm{s}^{-2}$ at about SP 6000, then increases to $\sim 140 \mu \mathrm{m} \mathrm{s}^{-2}$ at the northern end of the line. Superimposed on this field are three significant anomalies: a $\sim-70 \mu \mathrm{m} \mathrm{s}^{-2}$ asymmetric anomaly from SP 7300 to 5700 over interpreted rifted continental crust; a $130 \mu \mathrm{m} \mathrm{s}^{-2}$ ptp symmetric anomaly from SP 5700 to 3000 in the continent-ocean transition zone; and a $125 \mu \mathrm{m} \mathrm{s}^{-2}$ ptp asymmetric anomaly from SP 3000 to 1000 over seismically defined oceanic crust.

\section{Magnetic data}

The magnetic profile data for both modelled lines have had the International Geomagnetic Reference Field (IGRF; 2002.3 epoch) removed. These data have been further filtered and smoothed using 


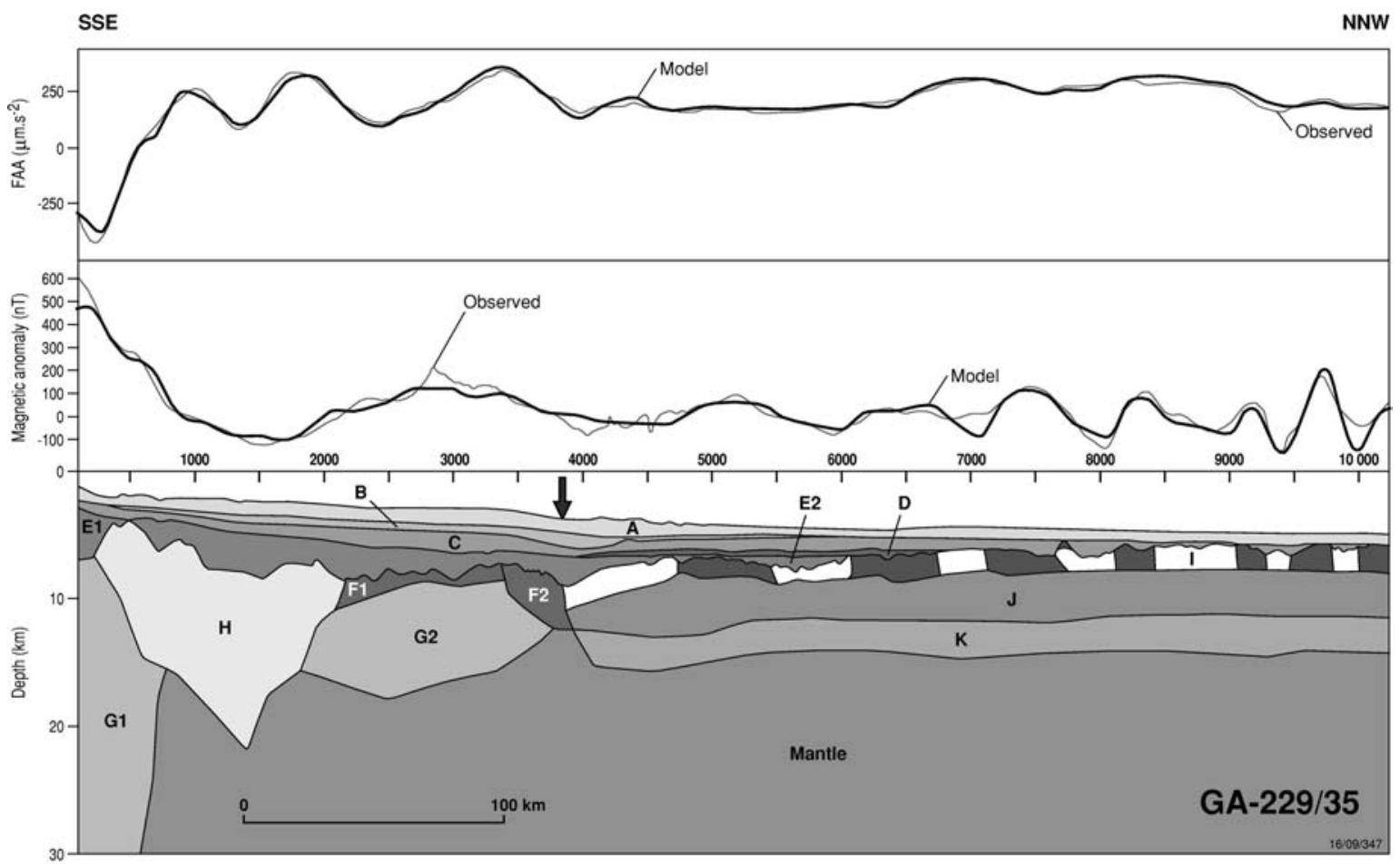

Figure 16. Potential field model for line GA-229/35, offshore western Enderby Land. Equivalent seismic profile is shown in Figure 6. Model bodies are identified in the text. Arrow shows inboard edge of oceanic crust.

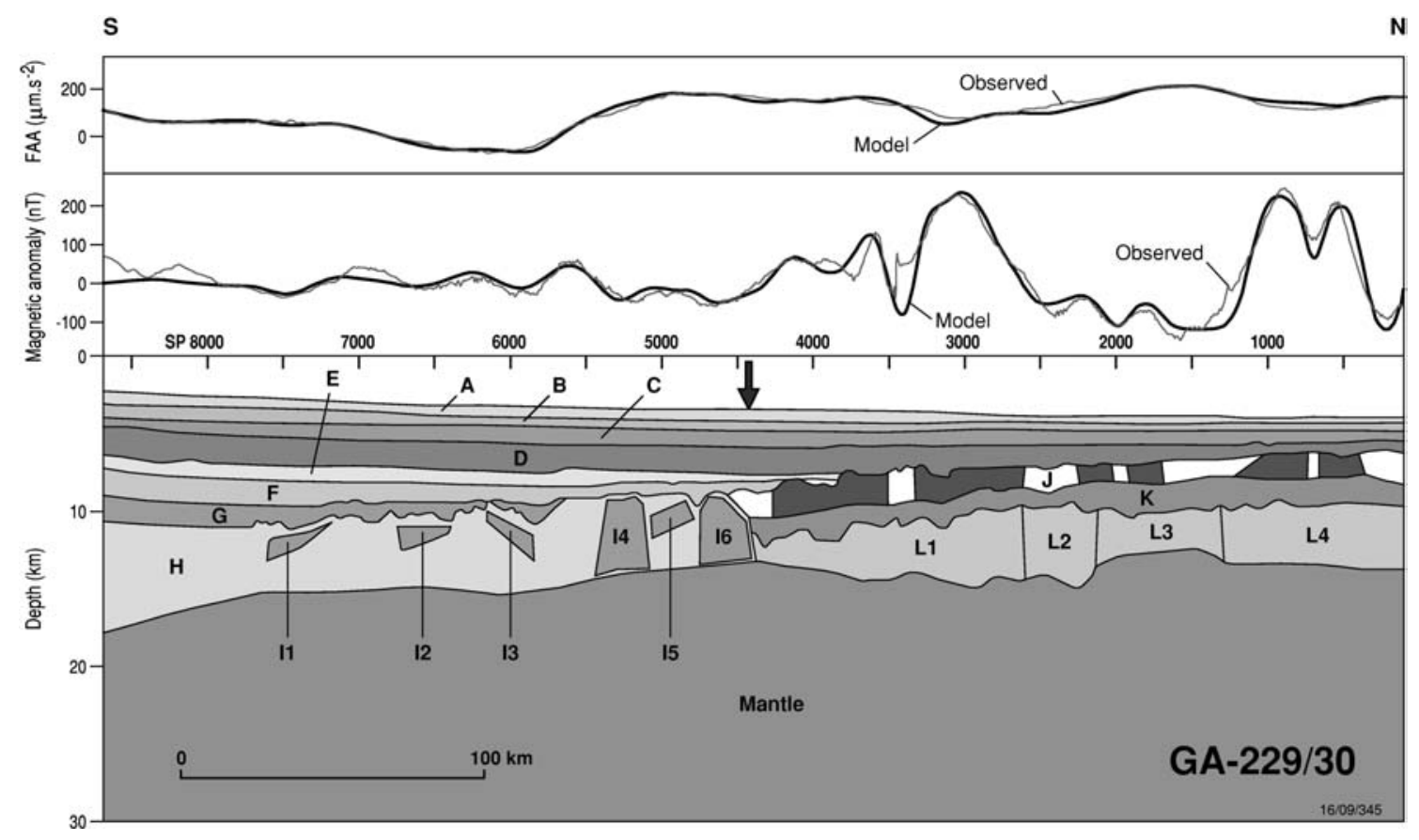

Figure 17. Potential field model for line GA-229/30, offshore Prydz Bay. Equivalent seismic profile is shown in Figure 9. Model bodies are identified in the text. Arrow shows inboard edge of oceanic crust. 
a three-point de-spiking and interpolation process, but have not been corrected for quiet day diurnal variation, or reduced to the pole. Thus, as well as remanent and induced magnetisations, the data will also include a time-variant component. High-frequency atmospheric noise is apparent in the profile (e.g., SP 2500-4000, GA-229/35; SP $6500-5000$, and the abrupt $\sim 80 \mathrm{nT}$ offset at about SP 3500 in GA-299/30 are probably storm-related.).

The parameters of the inducing magnetic field used in modelling were calculated using the geodetic coordinates of the midpoint of the line. The computed values for GA-229/35 were $\mathrm{B}=41,800 \mathrm{nT} ; \mathrm{I}=-63^{\circ} ; \mathrm{D}=-50^{\circ}$; and for $229 /$ $30 \mathrm{~B}=51,400 \mathrm{nT} ; \mathrm{I}=-69.7^{\circ} ; \mathrm{D}=-68.5^{\circ}$. The general north-south orientation of the lines and the line length of more than $400 \mathrm{~km}$ mean that there are significant departures from these values at the ends of the lines. Experimenting with the field values derived for the start and end of line locations $\left(-67.001^{\circ} \mathrm{S}, \quad 45.4403^{\circ} \mathrm{E}\right.$; and $-62.9021^{\circ} \mathrm{S}, 40.8479^{\circ} \mathrm{E}$ for $229 / 35 ; 62.2818^{\circ} \mathrm{S}$ $72.1501^{\circ} \mathrm{E}$ to $66.1321^{\circ} \mathrm{S} 72.2354^{\circ} \mathrm{E}$, for GA229/30) showed a maximum $1800 \mathrm{nT}$ difference in the inducing field strength, a $1^{\circ}$ change in the inclination, and $3^{\circ}$ change in the declination compared to the field values used in modelling. Further trials of the impact of changing these variables during modelling showed that these result in a maximum 0.2 change in the RMS error compared to the RMS error of the models with the mid-point parameters. Consequently, the difference in inducing field strength across the lines is not considered significant. The IGRF-corrected magnetic field in both lines shows a base level of $\sim 0 \mathrm{nT}$, indicating adequate modelling of the geocentric axial dipole field in this region.

On line GA-299/35, superimposed on this regional baseline are a series of $\sim 120 \mathrm{~km}$ spatial wavelength anomalies, with superimposed high frequency noise from the southern end of the line to about SP 3500. These anomalies have amplitudes of 200-600 nT ptp and are interpreted to be derived from continental crust, based on the seismic interpretation. North of about SP 4000, the residual field shows pronounced high-amplitude, variable-wavelength anomalies. These anomalies have half-wavelengths of $\sim 30-60 \mathrm{~km}$, and amplitudes of 30-260 nT ptp. High-frequency noise (average $20 \mathrm{nT}$ ptp), which may be either instru- mental noise or atmospheric transient signals, is superimposed on these anomalies; these high-frequency signals were not modelled.

On line GA-229/30, the regional field is augmented by a series of $\sim 80 \mathrm{~km}$ spatial wavelength anomalies with superimposed high frequency noise from the southern end of the line to SP 4500, associated with seismically defined continental crust. The average amplitude of these anomalies is $75 \mathrm{nT}$ ptp. Seaward of SP 4500, the magnetic character changes markedly, with pronounced high-amplitude, variable-wavelength anomalies being associated with seismically defined oceanic crust. These anomalies have halfwavelengths from $\sim 25$ to $\sim 40 \mathrm{~km}$, and amplitudes of 40 to $200 \mathrm{nT}$ ptp. They also display high-frequency superimposed noise (average 20 nT ptp).

\section{Line GA-229/35 (western Enderby Land; Figure 16)}

Model bodies A to E (Figure 16) correspond to the post-rift sedimentary section. The densities of these bodies range from 1.89 to $2.45 \times 10^{3} \mathrm{~kg} \mathrm{~m}^{-3}$, and all bodies are non-magnetised.

The major density change (from 2.45 to $2.8 \times 10^{3} \mathrm{~kg} \mathrm{~m}^{-3}$ ) takes place at the transition from rift/pre-rift to post-rift sediments interpreted at the base of bodies E1 and E2. This corresponds to a change in seismic character from high-amplitude, high-continuity, laminar reflections in the shallow section, to more discontinuous reflections at depth that are offset by interpreted seaward-dipping normal faults. The base of bodies F1 and F2 is relatively unconstrained, with no corresponding seismic reflection boundary with the underlying bodies. F1 and F2 (and the equivalent thickness of the top of body $\mathrm{H})$ thus may represent the fault-disrupted top of basement.

The high-velocity, pre-rift basement forms two distinct packages resolvable in the potential field analysis. Bodies $\mathrm{G} 1$ and $\mathrm{G} 2$ are dense $\left(2.8 \times 10^{3} \mathrm{~kg} \mathrm{~m}^{-3}\right)$, normally magnetised units which produce significant high-amplitude, longwavelength magnetic anomalies. The seismic character is diffuse with steeply dipping reflectors. G1 and $\mathrm{G} 2$ are interpreted as ?Archaean-Proterozoic metamorphic basement rocks, such as schists or gneisses, that have high velocities, densities and 
significant anisotropy. Non-magnetic, continuous, steeply dipping reflectors in the seismic data are interpreted as major ductile shear zones, consistent with this interpretation. G1 and G2 are therefore likely to be equivalent to the exposed rocks of the Eastern Ghats of peninsular India.

Bodies $\mathrm{G} 1$ and $\mathrm{G} 2$ are separated by body $\mathrm{H}$, a thick, broad wedge of reversely magnetised rocks, of similar metamorphic basement density. This body is required to fit the long wavelength $(120 \mathrm{~km})$ high-amplitude (300 nT) low in the magnetic signal. Such a large feature can either be explained by a shallow tabular magnetised source (e.g., sill complex) for which there is no velocity or seismic reflection evidence, or by a deep-seated basement feature. We have chosen the latter to model this anomaly. This body may be a Palaeozoic or Proterozoic infra-rift basin, equivalents of which may be exposed on the conjugate east Indian coast and hinterland (e.g., Cuddapah Basin). If this interpretation is correct, the basin may trend at a high angle to the present rifted margin, and the seismic transect is likely to image it obliquely. In conjunction with its antiquity, this geometric effect may account for the general lack of seismic reflectivity from this body, and also means that the modelled architecture of the basin and its underlying basement may not be representative of the overall structure of this crustal element, especially towards the landward end of the line.

Metamorphic basement overlies a high density body $\left(3.4 \times 10^{3} \mathrm{~kg} \mathrm{~m}^{-3}\right)$ at $10-40 \mathrm{~km}$ depth, interpreted as continental lithospheric mantle.

The oceanic crystalline crust interpreted from the reflection seismic data has been modelled using a variable three-layer structure. As no internal crustal layering is discernible in the reflection seismic data, the layers that are used as the basis for the potential field model are derived from the velocities listed in Table 1. The upper layer (body I) is bounded at its top by a rugose basement surface that shallows to the north. All blocks in this layer are modelled with the same density $\left(2.55 \times 10^{3} \mathrm{~kg} \mathrm{~m}^{-3}\right)$, but the magnetic susceptibilities vary from 0.005 to 0.05 SI, and the Konigsberger Ratios vary from 0.5 to 2 .

Underlying the normal and reversely magnetised blocks is a single high-density layer (body $\mathrm{J}$; $2.75 \times 10^{3} \mathrm{~kg} \mathrm{~m}^{-3}$ ) with negligible magnetisation, interpreted as relatively unaltered dolerite dyke swarms and/or layered gabbro (oceanic layer $2 \mathrm{~B} /$ 3). This is, in turn, underlain by a uniformly denser layer (body $\mathrm{K} ; 2.85 \times 10^{3} \mathrm{~kg} \mathrm{~m}^{-3}$ ) of nonmagnetised peridotites (oceanic layer 3 ).

A notable feature of the boundary between the rifted and attenuated continental crust and distinctive oceanic crust in this model is the generally low-amplitude ( $\sim 200 \mu \mathrm{m} \mathrm{s}^{-2}$ ptp) gravity response, and the broad wavelength $(\sim 80 \mathrm{~km})$, negative magnetic anomaly. In this case, the subdued magnetic signature is due to an edge effect where non-magnetic supracrustal rocks are in contact with magnetised, negative polarity seafloor crust. Both crustal columns have approximately the same overall bulk average density, leading to little gravity discrimination of the transition between the crustal types. This situation highlights the degree of complexity that is potentially involved in the transition from continental to oceanic crust, and consequently the interpretation of the magnetic or gravity data without reference to the seismic data can produce an erroneous estimate of the position of this transition on the margin, due to complex edge effects.

\section{Line GA-229/30 (offshore Prydz Bay; Figure 17)}

Model bodies A to $G$ (Figure 17) represent the rift and post-rift sedimentary section. The densities of these bodies range from 1.82 to $2.49 \times 10^{3} \mathrm{~kg} \mathrm{~m}^{-3}$, and bodies $\mathrm{A}$ to $\mathrm{F}$ are non-magnetised. The transition from rift/pre-rift to post-rift sediments is located at the boundary between bodies $F$ and $G$. The total thickness of sediments is almost $9 \mathrm{~km}$, most of which is of post-rift origin. Body $\mathrm{G}$ is distinguished by an apparent reversed magnetisation, interpreted to be due to interbedded mafic volcanic detritus or lavas.

Normal faults controlling the deposition of body $\mathrm{G}$ cut down into basement that has a noisy, diffuse seismic character. This basement (body $\mathrm{H}$ ) has been modelled with a significantly higher density than the sedimentary section $(2.9 \times$ $10^{3} \mathrm{~kg} \mathrm{~m}^{-3}$ ) and with minor normal magnetisation ( $k=0.008 \mathrm{SI}$, normal polarity). Basement is interpreted to be metamorphic rocks of the continental shield. Onshore to the west of Prydz Bay, there is an exposed gneissic basement (Napier Complex) of mixed marbles, calc-silicates, mafic orthoamphibolites, and garnet-bearing gneisses (Tingey, 
1991), which would produce a response consistent with the properties of body $\mathrm{H}$.

The distinctive, higher-amplitude, longer-wavelength magnetic anomalies associated with this crust have been modelled with discrete highly magnetised bodies (bodies I1-I6). These may represent syn-rift mafic intrusions (e.g., dykes, plugs), compartments of syn-rift volcanics, or alternatively, magnetic amphibolites within metamorphic basement. These bodies have high densities $\left(2.90 \times 10^{3} \mathrm{~kg} \mathrm{~m}^{-3}\right)$, equal to that of the surrounding basement, but these densities are non-diagnostic of any of the proposed sources. The significant magnetisations attributed to these bodies are all apparently reversed, perhaps indicating a temporal link to the reversed signature of the syn-rift layered sedimentary package (body $G$ ), although this is not conclusive evidence of their origin.

The oceanic crust interpreted from the reflection seismic data in this sector has also been modelled using a variable three-layer structure. The upper layer (body $\mathrm{J}$ ) is bounded at its top by a rugose basement surface with occasionally rugged topography that shallows northwards with an average gradient of about $0.6^{\circ}$. Normally and reversely magnetised blocks in this layer have highly variable densities, from 2.45 to $2.8 \times 10^{3} \mathrm{~kg} \mathrm{~m}^{-3} \quad$ (average $2.58 \times 10^{3} \mathrm{~kg} \mathrm{~m}^{-3}$ ), perhaps indicative of variable hydrothermal alteration and submarine weathering. The modelled magnetic susceptibilities are also quite variable, ranging from 0.006 to $0.06 \mathrm{SI}$, with Konigsberger Ratios of 1-2.

The crust underlying the upper layer is modelled with a dense, $\left(\rho=2.85 \times 10^{3} \mathrm{~kg} \mathrm{~m}^{-3}\right)$ nonmagnetised layer (body $\mathrm{K} ; \rho=2.85 \times 10^{3} \mathrm{~kg} \mathrm{~m}^{-3}$; $k=0 \quad \mathrm{SI})$. Sonobuoy stations give refraction velocities from the near the top of this body that indicate it is probably oceanic layer 3. Beneath this is a layer of variable density and magnetisation (body L), interpreted as faulted and altered oceanic peridotites of oceanic layer 3 . Four main blocks are modelled in this lower layer, with the boundary between L3 and L4 corresponding to the boundary between the seismically defined ebo 2 and ebo 1 crust. Whereas three of the four blocks have high densities (average $2.90 \times 10^{3} \mathrm{~kg} \mathrm{~m}^{-3}$ ) and are non-magnetised, the outermost block of the ebo 2 crust has a significantly lower density (L3: $\rho 2.75 \times 10^{3} \mathrm{~kg} \mathrm{~m}^{-3}$ ) and an unusually high component of normal magnetisation ( $k=0.05 \mathrm{SI} Q=1.5$ ). These variations in properties and in seismic character, and the significant variations in properties of the shallow basaltic layer, are interpreted to reflect the widespread influence of hydrothermal alteration (spilitisation) of the basalts, and widespread serpentinisation of the peridotites around active faults through the oceanic crust (e.g., Minshull et al., 1998). If this is the case, hydrothermal fluids either from above or below may have been mobilised through the crust, altering reactive olivine to serpentine and magnetite, and simultaneously reducing the density and increasing the magnetic susceptibility.

The bulk mantle under this transect has a higher density than on line GA-229/35 off western Enderby Land. This higher than normal density $\left(\rho=3.4 \times 10^{3} \mathrm{~kg} \mathrm{~m}^{-3}\right)$, confirmed by seismic refraction sonobuoy modelling (Table 1), may be indicative of metasomatism or igneous underplating of the mantle during the Palaeozoic formation of the Lambert Graben. The Moho under oceanic crust appears in places as a broken, high amplitude reflector with up to $2 \mathrm{~km}$ of relief, indicative of tectonic complexity. This appears to be localised under the lowest density panel of the oceanic crust described above (body L3), perhaps indicating either through-going lithospheric-scale shear zones or soft-linked (i.e. viscously decoupled or non-throughgoing) shear systems, with linked fluid transfer pathways.

The boundary between attenuated continental crust and oceanic crust on this profile is within a zone of long-wavelength, high amplitude ( $\sim 200 \mu \mathrm{m} \mathrm{s}^{-2}$ ptp) gravity signature, and negative $(\sim-50 \mathrm{nT})$, moderate wavelength $(\sim 30 \mathrm{~km})$ magnetic anomaly. No single anomaly marks the inferred contact between the two types of crust. In this case, the broad negative magnetic signature is due to reversely magnetised intrusions within the continental metamorphic basement adjacent to more weakly remanently magnetised, negative polarity seafloor crust, with little discrimination between the two on magnetic grounds. This situation, different to GA-229/35 above, but similar in other respects, again highlights the degree of complexity that is involved in areas of continent-ocean transition, and the importance of deep-seismic reflection data, as 
well as refraction and potential field data, in locating this transition and defining its structure.

\section{Synthesis of potential field modelling}

Both transects modelled for this paper show a relatively uncomplicated transition from rifted continental to oceanic crust. The post-rift sections are strikingly similar in stratal geometry, seismic character and potential field character. These strata wedge out to an approximately constant thickness of $\sim 1.5 \mathrm{~km}$, overlying a rough oceanic basement, with interpreted M-series magnetic anomalies (Brown et al., 2003). This crust appears to have formed during several discrete episodes of generation, with differing seismic reflection, velocity and density characteristics. This crust is readily distinguishable from the more uniform seismic reflection and velocity characteristics of the Archaean shield metamorphic basement which underlies the continental margin further inboard. The transition from thinned continental to oceanic crust in this sector thus reflects a significant sharp character change in the seismic reflection and velocity data, particularly off Mac. Robertson and western Enderby Lands, which is replicated by a distinct boundary in the potential field models. However, the transition is not always clearly defined in the magnetic signal, due to the presence of remanently magnetised intrusions within the adjacent continental crust. These intrusions can produce obscuring, longer wavelength magnetic anomalies.

The potential field modelling also indicates distinct differences between the oceanic crust of the western and eastern sectors. The crust off western Enderby Land (Figure 16) is slightly thinner and it shows less variation in thickness and in magnetic properties below the basalt layer than the crust off Mac. Robertson Land (Figure 17). In both profiles, the continental and oceanic crusts have behaved as a semi-rigid plate that has been depressed landwards by the thick (4-9 km) post-rift sediment loading.

\section{Post-rift sedimentary section}

The sedimentary section on the margin of Mac. Robertson and Enderby Lands is extremely thick, particularly offshore from Prydz Bay. Sediment thicknesses computed from seismic process- ing stacking velocity analyses and potential field modelling (see above) indicate that the sedimentary section below the continental slope oceanward of Prydz Bay is at least $8 \mathrm{~km}$ thick. Most of the section that is visible in seismic data is of post-margin breakup age (i.e., Upper Cretaceous and Cainozoic); these sediments are underlain by an unknown thickness of rift and pre-rift sediments that cannot be reliably distinguished in seismic data because of the immense overburden. The post-rift section thins gradually oceanwards, but it is still more than $2 \mathrm{~km}$ thick at more than $500 \mathrm{~km}$ from the shelf edge. Offshore from Enderby Land in the west, the post-rift sediments are generally thinner than off Prydz Bay, but there is still more than $8 \mathrm{~km}$ of this section in some inboard locations.

The post-rift sedimentary section can be divided into four distinct provinces. From east to west, these are: offshore from eastern Prydz Bay $\left(75-80^{\circ} \mathrm{E}\right)$; offshore from western Prydz Bay to eastern Mac. Robertson Land (65$75^{\circ} \mathrm{E}$ ); offshore from western Mac. Robertson Land, Kemp Land and eastern Enderby Land $\left(50-65^{\circ} \mathrm{E}\right)$; and offshore from western Enderby Land $38-50^{\circ} \mathrm{E}$.

The eastern Prydz Bay sector is characterised by a prograding shelf edge and upper slope of Cainozoic sediments that passes seawards into a sedimentary section at least $4 \mathrm{~s}$ TWT thick (Figure 5b). The prograding wedge is composed largely of diamicts deposited by slumping of subglacial debris delivered to the shelf edge by an expanded Lambert Glacier (Barron et al., 1989). The sediments beneath the slope and rise show moderate reflector continuity and variable amplitude. The upper part of the section shows extensive canyons, channels and levee deposits indicating a predominance of transport and deposition by down-slope currents.

The western Prydz Bay province has a very thick slope and rise section (Figures 8 and 9; Kuvaas and Leitchenkov, 1992). The basal 1-2 s TWT of the sedimentary section displays similar moderately-continuous reflectors as to the east, but the upper 2-3 s TWT comprises large sediment mounds with high-continuity reflectors, areas of mud waves and stacked channel-levee complexes with abundant evidence of vertical accretion. The largest mounds trend north-northwest and are separated by the broad canyons. 
Small-displacement faults are widespread, suggesting out-of-section slumping into the canyons. Kuvaas and Leitchenkov (1992) interpreted the mounds as mixed contourite-turbidite drifts formed by contour current reworking of sediment delivered to the slope and rise by turbidity currents, mostly emanating from Prydz Bay. ODP Site 1165 was drilled to $999.1 \mathrm{~m}$ below sea floor on a sediment drift northwest of Prydz Bay (Figure 8; O'Brien et al., 2001; Cooper and O'Brien, 2004). It encountered Early Miocene contourites that passed upwards into contourites, hemipelagic muds and oozes with evidence for rapidly reducing current activity and sedimentation rates through the Late Miocene and Plio-Pleistocene. Plio-Pleistocene deposition was concentrated on the upper slope where the Lambert Glacier built a trough mouth fan that downlaps on to the major Miocene drifts (Passchier et al., 2003; O'Brien et al., 2004).

In the western Mac. Robertson to eastern Enderby Land sector, the upper 1-2 s TWT of sediment includes smaller mounds that show some characteristics of contourite drifts but which are cut by numerous canyons and gullies (Figure 5a). These sediments do not exhibit the channel-levee deposits that are dominant to the east, but generally appear to be deposits that are presently being dissected by down-slope currents. However, some canyon-fill deposits are also present (e.g., southern end of line 228/06, near the intersection with TH99-27; Figure 5a). More distal regions show moderate-continuity reflectors and small channels suggesting distal submarine fan deposition (e.g., Figure 5a; line TH99-06). The deeper sedimentary section is generally similar in character to areas to the east, with moderate-continuity reflectors that onlap oceanic crust seaward.

The western Enderby Land sector is characterised by a thick sedimentary section $(>6 \mathrm{~km})$ in which the thickest sediments appear to be older than those offshore Prydz Bay. These sediments are thickest beneath the landward end of the lines and thin rapidly seaward, pinching out against oceanic crust (Figures 6 and 7). The sequence is heavily dissected by channels that range in scale from large canyons to small tributary gullies. Probable Cainozoic contourite sediments onlap the upper surface of this sediment pile. This Cainozoic section is characterised by high-continuity, parallel reflectors with some mudwaves. In places there is a well-developed moat at the inboard edge of this deposit indicating contourite sedimentation (Faugère et al., 1999). Farther outboard on the margin, channel and levee deposits are visible at the seabed indicating distal submarine fan sedimentation is currently taking place.

\section{Discussion}

Figure 18 summarises the tectonic elements of the continental margin of Enderby Land, the adjacent deep-ocean basins and the southern Kerguelen Plateau. This map is a synthesis of the interpretation presented in this paper with previously published information on the structure and age of the Enderby Basin (Rotstein et al., 2001; Brown et al., 2003) and the structure of the Kerguelen Plateau (Borissova et al., 2002). In broad outline, the main tectonic features are similar to those mapped by Gandyukhin et al. (2002).

The inboard part of the margin is dominated by the shallow crystalline basement of the Napier Complex. In the east, the north-south trending Palaeozoic-Mesozoic Lambert Graben has formed within the basement and this is, in turn, overlain by the approximately NE-SW trending Mesozoic-Cainozoic Prydz Bay Basin. As the Lambert Graben is a major feature of the onshore crust, it is likely that it also continues offshore beneath the marginal rift. However, with the extremely thick post-rift overburden and the orientation of the available seismic lines, it is not discernible offshore. The northern flank of the Napier Complex is generally delineated by a major fault zone that underlies the outer shelf and upper continental slope, beyond which basement deepens by at least $6-8 \mathrm{~km}$.

As shown in Figure 18, the deep-water part of the continental margin and the adjacent oceanic crust are divided into western and eastern sectors by the $\mathrm{N}-\mathrm{S}$ offset in the boundary between interpreted continental and unequivocal oceanic crust and the $\mathrm{E}-\mathrm{W}$ change in the character of oceanic crust at about $58^{\circ} \mathrm{E}$.

\section{Western sector}

In the western sector (west of $58^{\circ} \mathrm{E}$ ), the continental margin is underlain by a band of rifted 
and thinned crust north of the shelf-slope fault zone. This band is relatively narrow (100$200 \mathrm{~km}$ ), due to the influence of the mixed rifttransform nature of this part of the margin. The maximum sediment thickness here is $6-8 \mathrm{~km}$, with most of these sediments being of post-rift age. We propose the name 'Rayner Basin' (after Rayner Glacier, in western Enderby Land) for the major depocentre on this part of the margin.

The character of the oceanic crust in the western sector, with its highly variable basement surface, is likely to be a function of its location in a likely mixed rift-transform zone, as indicated by the irregular distribution of the identified magnetic anomalies and the fracture zone interpretation of Rotstein et al. (2001) (Figure 18). The panel of over-deepened crust (ebo 3) is more difficult to explain. As suggested above, its anomalous depth suggests that it is a remanent of a much older episode of seafloor spreading.

The oceanic crustal velocity structure of the western sector is distinctive, particularly in the deep crust below 'normal' layer 3. The highest velocities recorded here range from 7.6 to $7.95 \mathrm{~km} \mathrm{~s}^{-1}$, which could be considered representative of 'slow' mantle. However, the modelled depth for these refractions is in the range $9.5-12.3 \mathrm{~km}$, which results in a thickness of about $4 \mathrm{~km}$ for the overlying crust (Table 1). This is considerably less than the extreme minimum thickness of $5.0 \mathrm{~km}$ for oceanic crust noted by White et al. (1992), but is near to their average of $4.87 \mathrm{~km}$ for oceanic crust adjacent to nonvolcanic rifted margins (i.e. slow-spreading crust with a spreading rate $<2.0 \mathrm{~cm} \mathrm{a}^{-1}$ ) and $3.97 \mathrm{~km}$ for fracture zone crust. This indicates that either the $>7.6 \mathrm{~km} \mathrm{~s}^{-1}$ velocity is not from mantle, or that the crust is anomalous. While the computed spreading rate for the eastern part of the Enderby Basin does not qualify as slow-spreading crust on this definition (except immediately prior to the cessation of spreading), the orientation of the magnetic spreading anomalies (Figure 18) indicates that the spreading rate to the west is distinctly lower, and perhaps close to the $2.0 \mathrm{~cm} \mathrm{a}^{-1}$ referred to above; however, this explanation for the velocity profile is not considered likely. The existence of fracture zones to account for the apparently thinned crust is also a possibility off western Enderby Land; however, this requires that all the sonobuoys that recorded velocities
$>7.6 \mathrm{~km} \mathrm{~s}^{-1}$ were deployed close to or on fracture zones, and/or that the fracture zones in this region are very closely spaced, producing a broad zone of anomalous oceanic crust. A third possibility is that the $>7.6 \mathrm{~km} \mathrm{~s}^{-1}$ velocities derive from lower crust that has been strongly altered by the intrusion of mantle rocks. This possibility is consistent with the reflection seismic character of this crust, which shows a slightly higher reflectivity than the overlying crust with some discontinuous reflectors, but no distinct reflection Moho, as is found to the east.

\section{Eastern sector}

In the eastern sector, the rift beneath the continental margin is considerably broader (ca. $300 \mathrm{~km}$ ) than to the west, and the maximum sediment thickness is at least $8 \mathrm{~km}$, with the sediments again predominantly of post-rift age. The greater thickness of sediment here reflects the discharge of sediment from the Lambert Glacier and Prydz Bay. We propose the name 'Mawson Basin' (after Mawson Station) for the major E-W trending depocentre on this part of the margin.

The seismic character of oceanic crust in this sector is highly distinctive. In particular, the ebo 2 oceanic crust is strongly redolent of the oceanic crust along the Cuvier margin (Sayers et al., 2002) and in the southeast Argo Abyssal Plain (Stagg and Symonds, 1995), off northwest Australia. Oceanic crust with a similar reflection character is also observed in the deep basin between Bruce Rise and the southern Kerguelen Plateau (Shackleton Basin of Stagg et al., 2005). While the Argo crust is interpreted to have formed in the Late Jurassic (Mihut and Müller, 1998), spreading along the Cuvier margin commenced prior to anomaly M10 time (Valanginian; Larson et al., 1979), at the same time that spreading is interpreted to have commenced in the Enderby Basin (Brown et al., 2003; Gaina et al., 2003), and almost certainly contemporaneous with the crust in the Shackleton Basin. The half-spreading rates in the Cuvier and Enderby Basins are also comparable $-3.3 \mathrm{~cm} \mathrm{a}^{-1}$ in the Cuvier Basin (Larson et al., 1979) and about $3.4 \mathrm{~cm} \mathrm{a}^{-1}$ in the Enderby Basin based on the anomalies shown in Figure 18. The strong seismic character similarity between Cuvier and Enderby oceanic crust is consistent with this spreading history. 


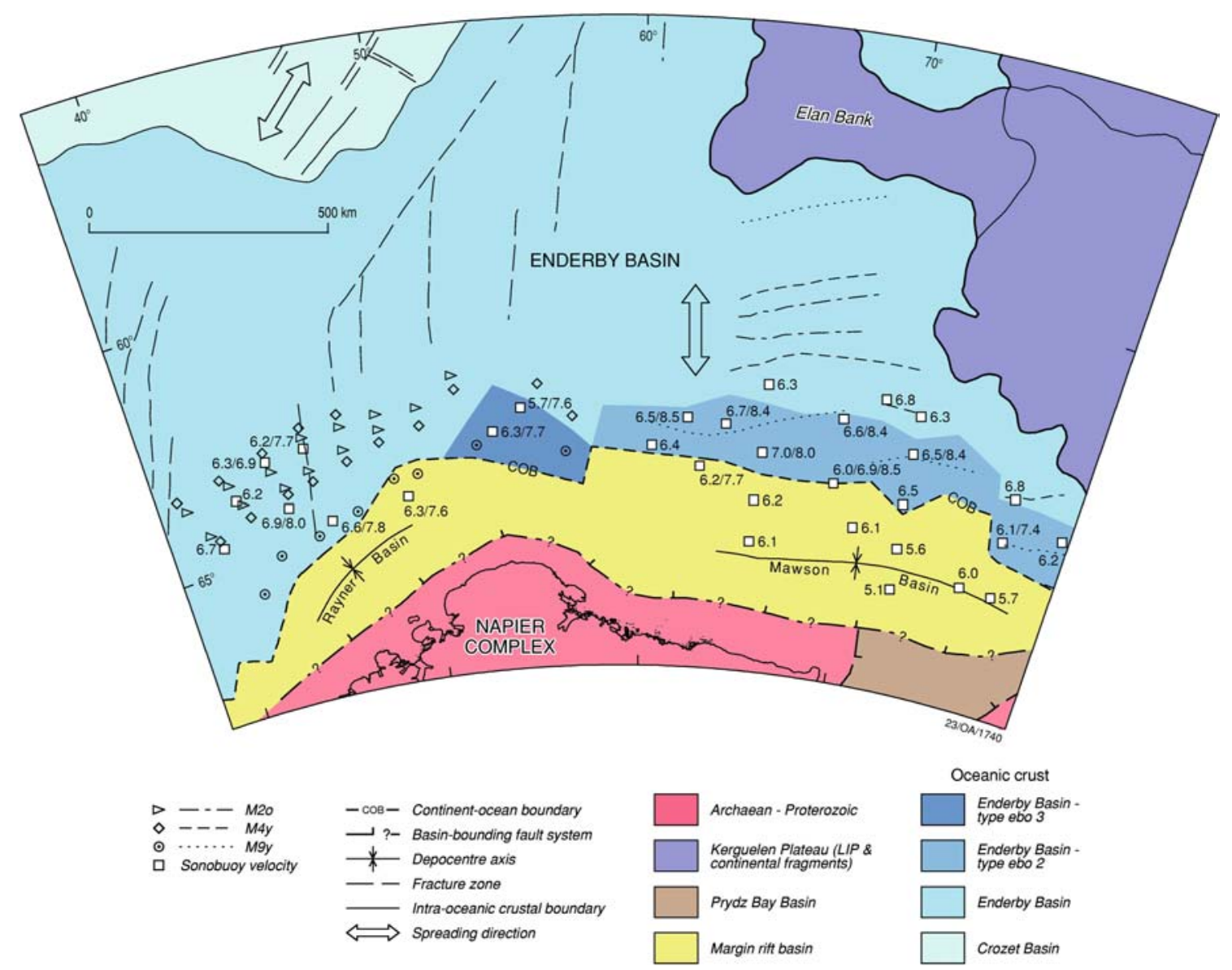

Figure 18. Tectonic elements map of the Enderby and Mac. Robertson Land margin and Enderby Basin. Fracture zone locations in the Enderby Basin are after Rotstein et al. (2001). Sonobuoy velocities from basement have been rounded to the nearest $0.1 \mathrm{~km} \mathrm{~s}^{-1}$.

The high-quality seismic images used in this study clearly show three sub-horizontal layers in the ebo2 crust; these may be related to the classical sub-divisions of oceanic crust as summarised, for example, by Kennett (1982). The uppermost $0.2-0.3 \mathrm{~s}$ TWT of basement is characterised by short, seaward dipping reflectors; these are likely to be the pillow basalts and sheet lava flows of Layer $2 \mathrm{~A}$. This layer is underlain by a layer that is largely transparent to seismic energy but which also contains faint sub-horizontal reflections, and a layer of highly reflective crust. The sonobuoys recorded in this sector show that the boundary between the transparent and reflective crustal layers approximately coincides with the onset of Layer 3 velocities. It is therefore possible that the transparent layer corresponds to the sheeted dykes of Layer $2 \mathrm{~B}$, while the highly reflective crust corresponds to the gabbros of Layer 3. The faint reflectors within the interpreted Layer $2 \mathrm{~B}$ possibly reflect hydrothermal alteration fronts within the sheeted dyke complex caused by the infusion of seawater early in the spreading history when the overlying sediment cover was thin. The combined thickness of $7 \mathrm{~km}$ for the dipping flows/transparent layer and the underlying reflective crust is very close to the world-wide thickness range of $7.1 \pm 0.8 \mathrm{~km}$ reported by White et al. (1992).

The highly reflective lower crustal layer within ebo 2 crust is characterised by

- high-amplitude reflections that dip consistently both landwards and oceanwards at about $30^{\circ}$;

- low-amplitude reflections that are antithetic to the high-amplitude reflections, giving the 
strong impression of fault-bounded tilt-blocks in the lower crust;

- a reflection Moho at the base of the crust that varies from moderate-amplitude and discontinuous to high-amplitude and high-continuity. The overlying dipping reflectors sometimes appear to correlate with offsets in the reflection Moho (e.g., Figure 12). Elsewhere, they sole out onto a reflection Moho that is a continuous, high-amplitude reflection (e.g., Figure 11).

The presence of structured reflections and high reflectivity zones within basement in oceanic crust has been reported in a number of papers (e.g., White et al., 1990; Mutter and Karson, 1992; Morris et al., 1993). Mutter and Karson (1992) concluded that the reflectivity of oceanic crust could be categorised in two ways. Firstly, in oceanic crust generated at 'slow' spreading rates (less than about $35 \mathrm{~mm} \mathrm{a}^{-1}$ ), they saw no obvious reflection Moho, while the main part of the crust exhibited a wide variety of reflecting horizons. Secondly, in crust generated at spreading rates greater than $50 \mathrm{~mm} \mathrm{a}^{-1}$, they typically found a strong reflection Moho, while the main part of the crust was essentially transparent to seismic energy. From these observations, Mutter and Karson (1992) developed a model in which continuous magma injection was the dominating process in fast-spreading crust, whereas in slowspreading crust, mechanical extension played the critical role.

As the spreading rate for the Enderby Basin oceanic crust is at the upper end of Mutter and Karson's (1992) slow spreading classification, it might be expected that this crust would show evidence of strong reflectivity while any reflections from Moho would be subdued or absent. However, the ebo 2 crust shows both pronounced lower crustal reflectivity and a strong Moho reflection with very high continuity (e.g., Figure 11). We also note that the reflection character in the ebo 2 crust is distinctly different to that reported by Mutter and Karson (1992), and it is therefore likely that their model cannot be applied here.

A further feature of the ebo 2-type crust is that it appears to have been emplaced over a relatively short period of about $4 \mathrm{My}$ at three widely separated locations on the axis of breakup between India and Australia-Antarctica - in the Enderby Basin; northwest of Bruce Rise some
$1000 \mathrm{~km}$ to the east; and along the Cuvier margin off northwest Australia (Sayers et al., 2002), $1500 \mathrm{~km}$ farther to the north. If the crust of the southeast Argo Abyssal Plain (Stagg and Symonds, 1995) is also included in this type, then there is a further example of this crust (albeit from an older spreading episode) $1500 \mathrm{~km}$ to the northeast of the Cuvier margin. While we have no ready explanation for the highly distinctive ebo 2-type crust, we note that in each case the crust has been emplaced adjacent to an area where large volumes of volcanics (including seaward-dipping reflector sequences, or SDRS) were generated at around the time of margin breakup.

The high-amplitude, landward-dipping mantle reflections observed on several lines are also difficult to explain. The reflections are observed on four adjacent lines over a distance of more than $250 \mathrm{~km}$ along strike on the margin. The strike of these reflections, which can be traced for about $8 \mathrm{~km}$ into the mantle, is sub-parallel to the continental margin and the boundary between ebo 2 and ebo 1 crust, implying that they are probably a primary geological structure formed coincidentally with spreading. These reflections are not observed in the other sectors (Bruce Rise and Cuvier margin) of this style of crust, but this might be due to the data quality in those areas. Reston (1993) reported widespread upper mantle reflections from offshore Britain (e.g., the Flannan mantle reflection) and concluded that most of these reflections were some form of extensional shear zone in the mantle. However, unlike the Cuvier-Enderby crust, the mantle reflections reported by Reston (1993) were located beneath continental crust. We are unaware of such reflections being reported from beneath oceanic crust.

\section{Continent-ocean Boundary}

Definition of the term 'continent-ocean boundary' (COB; also referred to as the ocean-continent boundary, OCB) in the continental margin geology literature has varied between authors. In this paper, we use the term continent-ocean boundary to refer to the inboard edge of unequivocal oceanic crust. Landward of the $\mathrm{COB}$, the continentocean transition (COT) refers to the region on the margin that lies between the outboard edge of highly attenuated continental crust and the COB. While the COT is predominantly of continental 
origin, it may also include magmatic components that have derived from the nearby emplacement of oceanic crust and possibly also areas of incipient oceanic crust.

As outlined in this paper, it is possible to discriminate oceanic crust from extended continental crust on the margins of Enderby and Mac. Robertson Lands on the basis of crustal velocities, reflection seismic character and the presence or absence of lineated magnetic anomalies. This discrimination is pronounced in the east, off Mac. Robertson and eastern Enderby Lands, but is considerably less clear further west, with the change occurring at the major offset in oceanic crustal types at approximately $58^{\circ} \mathrm{E}$ (Figure 18).

In the east, the $\mathrm{COB}$ is interpreted at the inboard edge of the highly distinctive type ebo 2 oceanic crust. On most lines over an along-margin distance of $800 \mathrm{~km}$ (e.g., Figures 5a, 8 and 10), this boundary correlates with a distinctive oceanwards step-up in basement level (from about 8 to $7.5 \mathrm{~s}$ TWT; this corresponds to a step of $500-1000 \mathrm{~m}$ over a distance of less than $5 \mathrm{~km}$ ). Gandyukhin et al. (2002) reported a similar basement step at the COB, while Joshima et al. (2001) and Brown et al. (2003) noted the presence of the prominent, high-amplitude Mac. Robertson Coast Anomaly in magnetic profiles at the same location.

Figure 10 shows the reflection seismic detail at the interpreted COB in this sector. On the left of the profile, the interpreted continent-ocean transition crust is characterised by broken reflections of variable amplitude that are probably due to a mixture of extensive small-scale fracturing of basement and widespread intrusion of oceanic magma as dykes and sills. On the right of the profile, the distinctive layered structure of the ebo 2 crust, with its underlying Moho reflection provides a marked contrast. The boundary between the two crustal types is a complex structure with a width of about $15 \mathrm{~km}$. At depth, the boundary is interpreted to be at the point where the strong reflection Moho disappears landwards. This also coincides with the landwards termination of the ebo 2 lower oceanic crust, with its characteristic dipping reflectors. In the shallow crust, the boundary is located at the base of the basement step (arrow in Figure 10), where it appears that seismically transparent volcanic flows have flowed landwards over the more reflective transitional crust.
West of the boundary in oceanic crustal types at $58^{\circ} \mathrm{E}$, the $\mathrm{COB}$ is much less distinctive, and our interpretation of its location is based largely on the oceanwards change in seismic reflection character (e.g., Figure 15). The interpreted continent/transitional crust on the left of this profile is characterised by a basement surface that appears to be downfaulted oceanwards towards a basement depression. In contrast, the interpreted oceanic crust on the right of the profile (type ebo 8) is essentially unbroken by faulting and the crust is almost transparent to seismic energy down to approximately $9 \mathrm{~s}$ TWT. On most lines in this sector (e.g., Figures 6 and 7), the change in seismic character from ?continental to oceanic crust appears to coincide with the zone of the deepest basement along the profile. Gandyukhin et al. (2002) also noted that the COB in the western sector is poorly expressed in seismic reflection data. On the basis of limited refraction data, they located their COB either at about the same geographic location as shown here (Figure 18), or even further seaward.

\section{Summary and conclusions}

The key points to come out of this study of the deep-water margin of East Antarctica from offshore western Enderby Land to offshore Princess Elizabeth Land are:

1. The shelf edge and upper slope are underlain by a major basin-bounding fault system, beyond which the crystalline basement underlying much of the shelf and immediate hinterland are downfaulted oceanwards by at least $6 \mathrm{~km}$. The continental margin is underlain by a rift basin that ranges from about $100 \mathrm{~km}$ wide off western Enderby Land to more than $300 \mathrm{~km}$ wide off eastern Enderby and Mac. Robertson Lands. The thickness of rift-phase sediments in this basin is uncertain, due to the loss of seismic energy in the very thick post-rift sedimentary section.

2. The sedimentary section appears to be primarily of post-rift age. This section is at least $8 \mathrm{~km}$ thick north of Prydz Bay and at least $6 \mathrm{~km}$ thick off western Enderby Land. The section thins gradually oceanwards, but is still greater than $2 \mathrm{~km}$ thick more than $500 \mathrm{~km}$ from the shelf edge. The post-rift sedimentary section can be 
divided into four distinct geographic provinces offshore from: eastern Prydz Bay; western Prydz Bay; west Mac. Robertson to east Enderby Land; and west Enderby Land. The division of these provinces is on the basis of the thickness of sediments present and the processes that controlled their deposition.

3. The margin is divided into distinct western and eastern sectors by a strong, north-south crustal boundary at about $58^{\circ}$ E. Structuring in the western sector appears to be strongly influenced by the mixed rift-transform setting. In contrast, the eastern sector was formed in a normal rifted margin setting, albeit with complexities caused by the major $\mathrm{N}-\mathrm{S}$ trending crustal-scale Lambert Graben and the overlying Prydz Bay Basin.

4. As with the marginal rift basins, the COB, defined here as the inboard edge of unequivocal oceanic crust, shows a marked change in character across the crustal boundary at $58^{\circ}$ E. In the western sector, the location of the $\mathrm{COB}$ is defined mainly on the basis of a change in the reflection seismic character, supplemented by potential field modelling; here, its location appears to coincide with the zone of deepest basement on the margin. However, in the eastern sector, the $\mathrm{COB}$ is a prominent and sharp boundary in the reflection seismic data which correlates with a marked change in the crustal velocity profile as shown by the interpretation of sonobuoy records. Potential field modelling confirms this interpretation. As noted by previous workers (Gandyukhin et al., 2002), this boundary often correlates with an oceanward step-up in the basement level of up to $1 \mathrm{~km}$.

5. The character of oceanic crust is also highly distinctive, again with a major west-to-east character change at $58^{\circ} \mathrm{E}$. In the western sector, the basement surface is of variable character, from rugged with a relief of more than $1 \mathrm{~km}$ over distances of $10-20 \mathrm{~km}$, to rugose with lowamplitude relief on long-wavelength undulations. The crustal velocity structure is unusual, with velocities of $7.6-7.95 \mathrm{~km} \mathrm{~s}^{-1}$ being recorded at several stations at a depth that gives a thickness of overlying crust of only $4 \mathrm{~km}$. It is possible that these velocities are from mantle, in which case the thin crust may be due to the presence of fracture zones. Alternatively, the velocities may be coming from a lower crust that has been heavily altered by the intrusion of mantle rocks. Oceanic crust in the eastern sector has a more typical oceanic velocity structure and is particularly characterised by its internal reflection fabric, which comprises: a smooth upper surface underlain by short, seaward-dipping reflectors; a transparent upper crustal layer, probably correlating with a sheeted dyke complex; a lower crust dominated by dipping highamplitude reflections that probably reflect intruded or altered shears; a strong reflection Moho, confirmed by refraction modelling; and prominent landward-dipping upper mantle reflections on several adjacent lines. Current models for reflective oceanic crust cannot be readily applied to this crust.

6. Potential field modelling indicates that the gross margin structure is relatively simple, and that both the continental and oceanic crusts have behaved as a semi-rigid plate that has been depressed landwards by the thick post-rift sediment loading.

An important feature of the work presented here is that the potential field modelling is closely integrated with the interpretation of the reflection seismic data. This integration leads to a major enhancement of the overall interpretation and greatly increases our confidence in the picking of major crustal boundaries.

The most significant shortcoming of the interpretation presented in this paper is the wide line spacing $(\sim 90 \mathrm{~km})$. Thus, while the high resolution and deep penetration of the data give an unprecedented insight into the structures of the margin, from the shallow section down to the upper mantle, we can only map the structures at a coarse scale. There is therefore a strong argument for an integration of all the datasets from this segment of the Antarctic margin, using the data interpreted here to provide an underpinning framework.

\section{Acknowledgements}

The interpretation underpinning this paper was carried out by the authors with contributions from L. Carson and D. Close. The seismic and potential field data were acquired by Fugro Geoteam AS, under contract to the Commonwealth of Australia, and their professionalism in 
acquiring and processing the data is acknowledged. We are grateful to German Leitchenkov for supplying the paper by Gandyukhin at al. (2002) which provided a valuable complement to our interpretation. We are also appreciative of the contributions of Barry Bradshaw and Kathe Trigg in reviewing this manuscript and of two anonymous reviewers. The figures were drafted by Silvio Mezzomo. This paper is published with the permission of the Chief Executive Officer, Geoscience Australia.

\section{References}

AGSO North West Shelf Study Group, 1994, Deep reflections on the North West Shelf: changing perceptions of basin formation, in Purcell P.G. and Purcell R.R. (eds.), The Sedimentary Basins of Western Australia, Proceedings of Petroleum Exploration Society of Australia Symposium, Perth, 1994, 63-76.

Banerjee, B., Sengupta, B.J. and Banerjee, P.K., 1995, Signals of Barremian (116 Ma) or younger oceanic crust beneath the Bay of Bengal along $14^{\circ} \mathrm{N}$ latitude between $81^{\circ} \mathrm{E}$ and $93^{\circ}$ E, Marine Geol. 128, 17-23.

Barron, J., Larsen, B. et al., 1989, Proceedings Ocean Drilling Program, Initial Report, vol. 119, 942 pp.

Borissova, I., Moore, A., Sayers, J., Parums, R., Coffin, M.F. and Symonds, P.A., 2002, Geological framework of the Kerguelen Plateau and adjacent ocean basins, Geoscience Australia Record 2002/05.

Brown, B.J., Ishihara, T. and Müller, R.D., 2003, Breakup and seafloor spreading between Antarctica, greater India and Australia, in D.K. Fütterer (ed.) Abstracts Ninth International Symposium on Antarctic Earth Sciences, Potsdam 8-12 September 2003, 40.

Coffin, M.F., Frey, F.A., Wallace, P.J. et al., 2000, Proceedings Ocean Drilling Program, Initial Reports, 183. Ocean Drilling Program, Texas A \& M University, College Station, TX.

Coggon J.H., 1976, The magnetic and gravity anomalies of polyhedra, Geoexploration, 14, 93-105.

Cooper, A.K. and O'Brien, P.E., 2004, Leg 188 synthesis: transitions in the glacial history of the Prydz Bay region, East Antarctica, from ODP drilling, in Cooper A.K., O'Brien P.E. and Richter, C. (eds.), Proceedings of the Ocean Drilling Program Scientific Results 188. http://wwwodp.tamu.edu/publications/188_SR/synth/synth.htm

Faugère, J.C., Stow, D.A.V., Imbert, P. and Viana, A., 1999, Seismic features diagnostic of contourite drifts, Marine Geol., 162, 1-38.

Gaina, C., Müller, R.D. Brown, B. and Ishihara, T., 2003, Microcontinent formation around Australia, in: Hillis R.R. and Müller R.D. (eds.), Evolution and Dynamics of the Australian Plate, Geological Society of Australia Special Publication 22 and Geological Society of America Special Paper 372, Chapter 26, pp. 399-410.

Gandyukhin, V., Gouseva, Yu, Kudryavtsev, G., Ivanov, S. and Leitchenkov, G., 2002, Crustal structure, seismic stratigraphy and tectonic history of the Cosmonaut Sea sedimentary basin (Antarctica, southern Indian Ocean), Explor. Protect. Mineral Resour. 9, 27-31.

Golynsky, A.V., Masolov, V.N., Nogi, Y., Shibuya, K., Tarlowsky, C. and Wellman, P., 1996, Magnetic anomalies of Precambrian terranes of the East Antarctic shield coastal region $\left(20^{\circ} \mathrm{E}-50^{\circ} \mathrm{E}\right)$, Proc. NIPR Symp. Antarctic Geosc. 9, 24-39.

Gradstein, F.M., Agterberg, F.P., Ogg, J.G., Hardenbol, J., van Veen, P., Thierry, J. and Huang, Z., 1994, A Mesozoic time scale. J. Geophy. Res., 99 (B12), 24051-24074.

Harris, P.T., O'Brien, P.E., Quilty, P.G., Taylor, F., Domack, E., DeSantis, L. and Raker, B., 1997, Vincennes Bay, Prydz Bay and Mac.Robertson Shelf, AGSO Cruise 186, post cruise report, Australian Geological Survey Organisation Record 1997/51.

Ishihara, T., Brown, B. and Joshima, M., 2000, M-series magnetic anomalies in Enderby Basin, EOS Trans. 81, F1130.

Joshima, M., Ishihara, T., Nakajima, T., Sugiyama, K., Tsuchida, K., Kato, A., Murakami, F. and Brown, B., 2001, Preliminary results of the TH99 geological and geophysical survey in the Cooperation Sea and Prydz Bay area, Polar Geosci. 14, 244-262.

Kennett, J.P., 1982, Marine Geology, Prentice Hall, 813 pp.

Kuvvas, B. and Leitchenkov, G., 1992, Glaciomarine turbidite and current controlled deposits in Prydz Bay, Antarctica, Marine Geol. 108, 365-381.

Larson, R.L., Mutter, J.C., Diebold, J.B., Carpenter, G.B. and Symonds, P., 1979, Cuvier Basin: a product of ocean crust formation by Early Cretaceous rifting off Western Australia, Earth Planet. Sci. Lett. 45, 105-114.

Lee, T. J., 1980, Rapid computation of magnetic anomalies with demagnetisation included, for arbitrarily shaped magnetic bodies, Geophys. J. Roy. Astronom. Soc. 60, 67-75.

Leitchenkov, G., Shelestov, F., Gandjuhin, V. and Butsenko, V., 1990, Outline of structure and evolution of the Cooperation Sea sedimentary basin, in Cooper A.K. and Webb P.N. (convenors) International Workshop on Antarctic Offshore Seismic Stratigraphy (ANTOSTRAT): Overview and Extended Abstracts, U.S. Geological Survey Open-file Report 90-309, 202-211.

Ludwig, W.J., Nafe, J.E. and Drake, C.L., 1970, Seismic refraction, in Maxwell, A.E. (ed.), New Concepts of Sea Floor Evolution, Part 1: Regional Observations, edited by Willey-Interscience, pp. 53-84.

Mihut, D. and Müller, R.D., 1998, Revised sea-floor spreading history of the Argo Abyssal Plain, in Purcell, P.G. and R.R. (eds.), The Sedimentary Basins of Western Australia 2, Proceedings of Petroleum Exploration Society of Australia Symposium, Perth, WA, 1998, pp. 73-80.

Minshull, T.A., Muller, M.R., Robinson, C.J., White, R.S. and Bickle, M.J., 1998, Is the oceanic Moho a serpentinisation front? In Mills, R.A. and Harrison, K. (eds.), Modern Ocean floor processes and the Geological Record, Geol Soc Lond Spec Pub 148, pp. 71-80.

Mizukoshi, T., Sunouchi, H., Saki, T. and Tanahashi, M., 1986, Preliminary report of the geological and geophysical surveys of Amery Ice Shelf, East Antarctica, Memoirs of the National Institute of Polar Research, Japan, Special Issue 43, 48-62.

Morris, E., Detrick, R.S., Minshull, T.A., Mutter, J.C., White, R.S., Su, W. and Buhl, P., 1993, Variations in seismic structure of Mesozoic aged crust in the western North Atlantic, J. Geophys. Res. 98, 13879-13904. 
Mutter, J.C. and Karson, J.A., 1992, Structural processes at slow-spreading ridges, Science 257, 627-634.

Nicolaysen, K., Bowring, S., Frey, F., Weis, D., Ingle, S., Pringle, M. and Coffin, M.F., 2001, Provenance of Proterozoic garnet-biotite gneiss recovered from Elan Bank, Kerguelen Plateau, southern Indian Ocean, Geology 29, 235-238.

O'Brien, P.E., Cooper, A.K., Florindo, F., Handwerger, D., Lavelle, M., Passchier, S., Pospichal, J.J., Quilty, P.G., Richter, C., Theissen, K.M. and Whitehead, J.M. in press, Prydz channel fan and the history of extreme ice advances in Prydz Bay, in Cooper, A.K. O'Brien, P.E. and Richter, C. (eds), Proceedings of the Ocean Drilling Program Scientific Results 188. http://www.odp.tamu.edu/publications/ 188_SR/016/016.htm

O'Brien, P.E., Cooper, A.K., Richter, C. et al., 2001, Initial Reports, Prydz Bay-Cooperation Sea, Antarctica: glacial history and paleoceanography. Proceedings Ocean Drilling Program, Initial Reports, 188 (CD-ROM), Texas A \& M University, College Station Texas.

O'Brien, P.E., Franklin, D. and O'Loughlin, M., 1993, Post cruise report, Prydz Bay and Mac. Robertson Shelf, Antarctica, January-March, 1993, Australian Geological Survey Organisation Record 1993/78.

O'Brien, P.E., Harris, P.T., Quilty, P.G., Taylor, F. and Wells, P., 1995, Post-cruise report, Antarctic CRC marine geoscience, Prydz Bay, Mac.Robertson Shelf and Kerguelen Plateau, Australian Geological Survey Organisation Record, 1995/29.

Passchier, S., O'Brien, P.E., Damuth, J.E., Janusczak, N., Handwerger, D.A. and Whitehead, J.M., in press, Pliocene-Pleistoncene glaciomarine sedimentation in eastern Prydz Bay and development of the Prydz trough-mouth fan, ODP Sites 1166 and 1167, East Antarctica, Marine Geol., 199, 279-305.

Prabhakar, K.N. and Zutshi, P.L., 1993, Evolution of southern part of Indian east coast basins, J. Geol. Soc. India 41, 215-230.

Quilty, P.G., Truswell, E.M., O'Brien, P.E. and Taylor, F., 1999, Paleocene-Eocene biostratigraphy and palaeoenvironment of East Antarctica: new data from the Mac.Robertson Shelf and western parts of Prydz Bay, AGSO J. Austr. Geol. Geophys. 17, 133-143.

Ramana, M.V., Nair, R.R., Sarma, K.V.L.N., Ramprasad, K.S., Subrahmanyam, M.D., Subrahmanyam, C., John, P., Subrahmanyam, D.V. and Sekhar, C., 1994, Mesozoic anomalies in the Bay of Bengal, Earth \& Planet. Sci. Lett. 121, 469-475.

Reston, T.J., 1993, Evidence for extensional shear zones in the mantle, offshore Britain, and their implications for the extension of the continental lithosphere, Tectonics 12 (2), 492-506.

Rotstein, Y., Munschy, M. and Bernard, A., 2001, The Kerguelen province revisited: additional constraints on the early development of the Southeast Indian Ocean, Marine Geophys. Res. 22, 81-100.
Sandwell, D.T. and Smith, W.H.F., 1997, Marine gravity anomaly from Geosat and ERS-1 satellite altimetry, Journal of Geophysical Research 102, 10039-10054.

Sayers, J., Borissova, I., Ramsay, D. and Symonds, P.A., 2002, Geological framework of the Wallaby Plateau and adjacent areas, Geoscience Australia Record 2002/21.

Seismic Image Software Ltd, 1995, SIGMA-1.0 Seismic Interpretation and Geological Modelling Application, Geological Survey of Canada (unpub.).

Sheraton, J.W., Black, L.P. and McCulloch, M.T., 1984, Regional geochemical and isotopic characteristics of high grade metamorphics of the Prydz Bay area: the extent of Proterozoic reworking of Archaean continental crust in East Antarctica, Precambrian Res. 26, 169-198.

Sheraton, J.W., Black, L.P., Tingey, R.J., Offe, L.A. and Ellis, D.J., 1987, Geology of Enderby Land and western Kemp Land, Bureau of Mineral Resources, Australia, Bulletin, 223.

Stagg, H.M.J., 1985, The structure and origin of Prydz Bay and the Mac.Robertson Shelf, East Antarctica, Tectonophysics 114, 315-340.

Stagg, H.M.J., Colwell, J.B., Direen, N.G., O’Brien, P.E., Brown, B.J., Bernardel, G., Borissova, I., Carson, L. \& Close, D.B., 2005, Geological framework of the continental margin in the region of the Australian Antarctic Territory, Geoscience Australia Record 2004/25.

Stagg, H.M.J. and Symonds, P.A., 1995, The Argo Abyssal Plain: a proposal to drill reflecting interfaces within oceanic crust, AGSO Record 1995/12.

Symonds, P.A., Planke, S., Frey, O. and Skogseid, J., 1998, Volcanic evolution of the western Australian continental margin and its implications for basin development, in P.G. and R.R. Purcell (eds.), The Sedimentary Basins of Western Australia 2, Proceedings of Petroleum Exploration Society of Australia Symposium, Perth, 1998, pp. 33-54.

Tingey, R.J., 1991, The geology of Antarctica, Oxford University Press, $680 \mathrm{pp}$.

Truswell, E.M., Dettmann, M.E. and O'Brien, P.E., 1999, Mesozoic palynofloras from the Mac. Robertson shelf, East Antarctica: geological and phytogeographic implications, Antarctic Sci. 11, 237-252.

Weis, D., Ingle, S., Damasceno, D., Frey, F.A., Nicolaysen, K. and Barling, J., 2001, Origin of continental components in Indian Ocean basalts: evidence from Elan Bank (Kerguelen Plateau - ODP Leg 183, Site 1137), Geology 29, 147-150,

White, R.S., Detrick, R.S., Mutter, J.C., Buhl, P., Minshull, T.A., and Morris, E., 1990, New seismic images of oceanic crustal structure, Geology 18, 462-465.

White, R.S., McKenzie, D. and O'Nions, R.K., 1992, Oceanic crustal thickness from seismic measurements and rare earth element inversions, J. Geophys. Res. 97(B13), 19683-19715. 